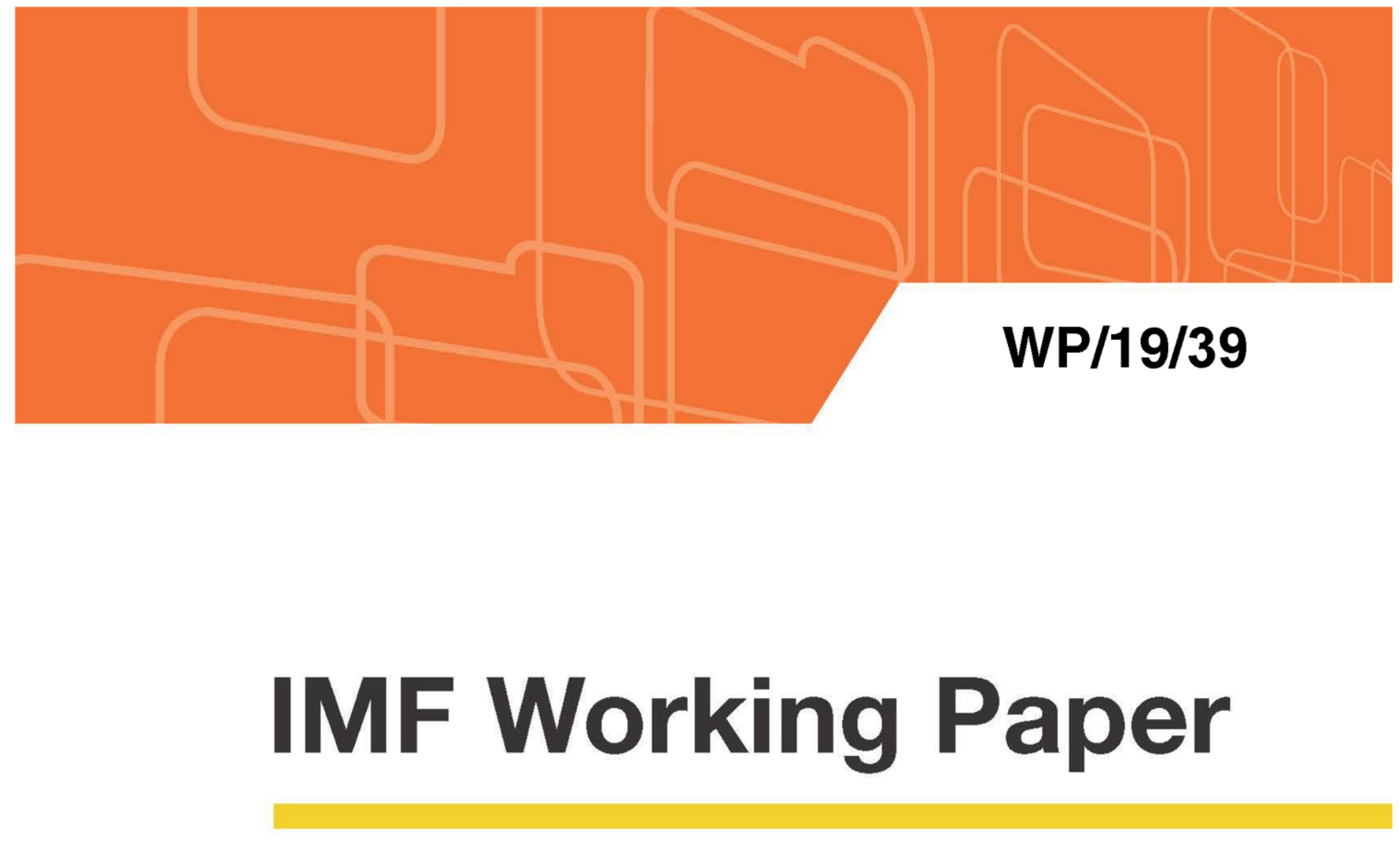

\title{
Credit Cycle and Capital Buffers in Central America, Panama, and the Dominican Republic
}

by Valentina Flamini, Pierluigi Bologna, Fabio Di Vittorio, and Rasool Zandvakil

IMF Working Papers describe research in progress by the author(s) and are published to elicit comments and to encourage debate. The views expressed in IMF Working Papers are those of the author(s) and do not necessarily represent the views of the IMF, its Executive Board, or IMF management. 


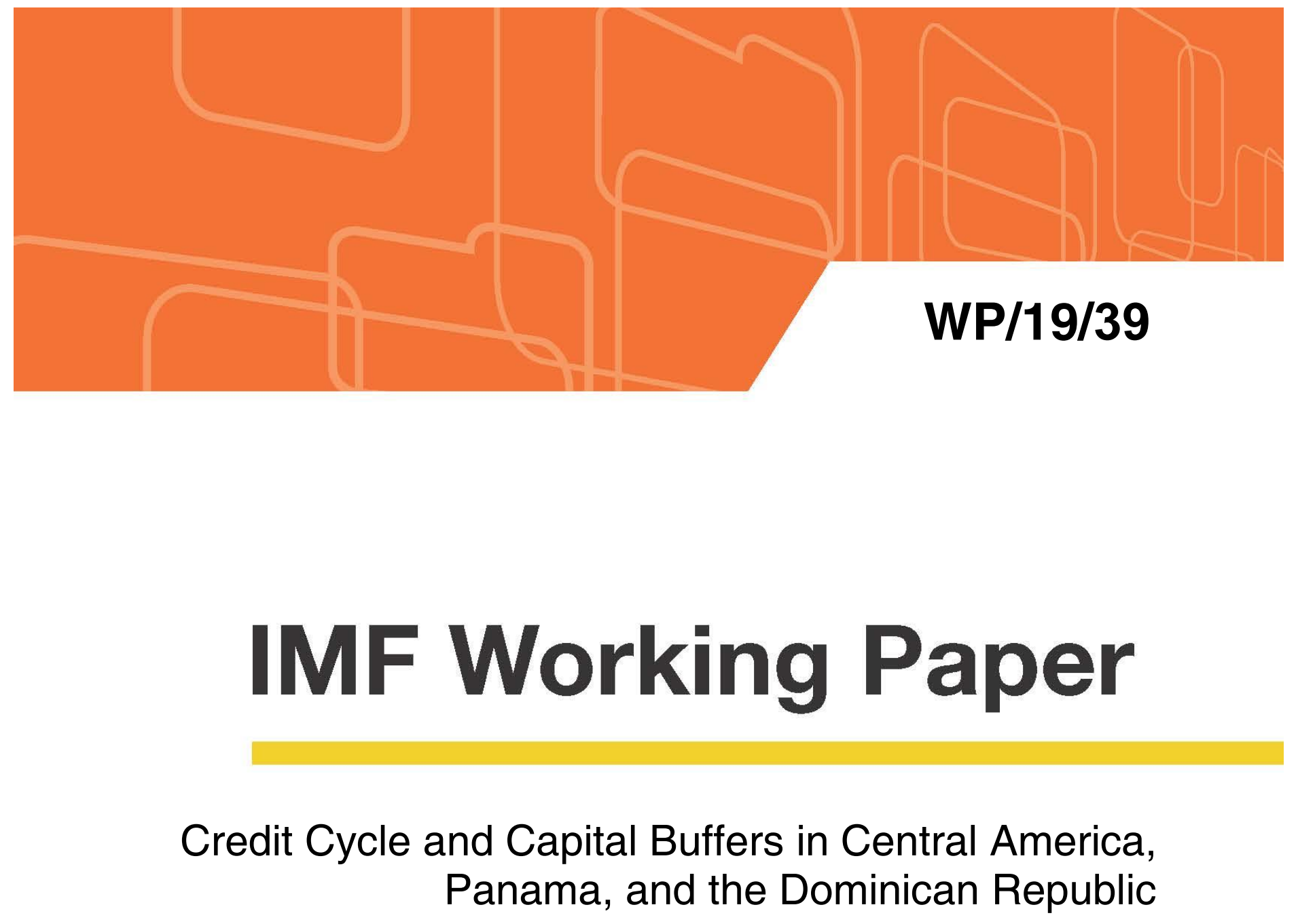

by Valentina Flamini, Pierluigi Bologna, Fabio Di Vittorio, and Rasool Zandvakil

IMF Working Papers describe research in progress by the author(s) and are published to elicit comments and to encourage debate. The views expressed in IMF Working Papers are those of the author(s) and do not necessarily represent the views of the IMF, its Executive Board, or IMF management. 


\title{
IMF Working Paper
}

\author{
Western Hemisphere Department
}

\section{Credit Cycle and Capital Buffers in Central America, Panama, and the Dominican Republic}

\author{
Prepared by Valentina Flamini, Pierluigi Bologna, Fabio Di Vittorio, \\ and Rasool Zandvakil
}

Authorized for distribution by Lorenzo Figliuoli

February 2019

IMF Working Papers describe research in progress by the author(s) and are published to elicit comments and to encourage debate. The views expressed in IMF Working Papers are those of the author(s) and do not necessarily represent the views of the IMF, its Executive Board, or IMF management.

\begin{abstract}
Credit is key to support healthy and sustainable economic growth but excess aggregate credit growth can signal the build-up of imbalances and lead to systemic financial crisis. Hence, monitoring the credit cycle is key to identifying vulnerabilities, particularly in emerging markets, which tend to be more exposed to sudden external shocks and reversal in capital flows. We estimate the credit cycle in Central America, Panama, and the Dominican Republic and find that the creadit gap is a powerful predictor of systemic vulnerability in the region. We simulate the activation of the Basel III countercyclical capital buffers and discuss the macroprudential policy implications of the results, arguing that countercyclical macroprudential policies based on the credit gap could prove useful to enhance the resilience of the region's financial sector but the activation of macroprudential instruments should also be informed by the development of other macrofinancial variables and by expert judgment.
\end{abstract}

JEL Classification Numbers: E30, E44, E50, G10, G20, G28

Keywords: Credit cycle, Financial crises, Countercyclical capital buffer, Basel III

Author's E-Mail Address: VFlamini@imf.org, FDiVittorio@,imf.org, RZandvakil@,imf.org, Pierluigi.Bologna $@$ bancaditalia.it $^{1}$

\footnotetext{
${ }^{1}$ The authors are thankful to Carolina Friend for excellent administrative assistance, and IMF colleagues for useful comments during the review process. The views expressed in this paper are those of the authors and should not be attributed to the Bank of Italy or the Eurosystem.
} 
This page intentionally left blank 
I. Introduction

II. Financial Markets And Credit in CAPDR $\underline{4}$

III. Estimating the Credit Cycle: Methodology and Data I

IV. Where Do CAPDR Countries Stand in the Credit Cycle?

V. Early Warning Power of the Credit-to-GDP Gap $\underline{13}$

VI. Activation of the Countercyclical Capital Buffer $\underline{18}$

VII. Conclusions and Policy Recommendations

\section{Figures}

1. CAPDR: Selected Banking Sector Indicators

2. CAPDR: Credit Cycle by Country

3. CAPR Credit Cycle: Similarity and Synchronicity

4. CAPDR: Activation of the Countercyclical Capital Buffer

5. CAPDR: System-wide CAR and Simulated Minimum Requirement

$\underline{21}$

\section{Tables}

1. CAPDR: Synchronicity and Amplitude of Credit Cycles

2. CAPDR: Early Warning Properties of the Credit Gap

3. CAPDR: Early Warning Properties of the Credit Gap

4. CAPDR: Early Warning Properties of the Credit Gap

\section{Appendix}

Data Description

\section{References}

References 


\section{INTRODUCTION}

Credit is key to support healthy and sustainable economic growth. Bank lending as well as non-bank sources of credit can foster financial deepening and generate economic growth and development, provided that resources are allocated efficiently. A moderate degree of leverage in the corporate sector can contribute to sound productive investments. Bankers and creditors' ability to select and appraise borrowers' credit worthiness can help maintain a sound banking system.

However, excessive aggregate credit growth can signal the build-up of imbalances and lead to systemic financial crisis. Too strong credit growth has been identified in a number of studies as one of the main causes of systemic financial crises (among others, Kaminsky and Reinhart, 1999, Laeven and Valencia, 2008, Schularick and Taylor, 2012). Excessive leverage can make banks and financial firms more vulnerable to shocks to their balance sheet, harming their ability to support the economy. There is a pro-cyclical bias to systemic risk, with financial institutions taking on excessive amounts of risk in the upswing of a cycle only to become overly risk-averse in the downswing. This characteristic amplifies the boom and bust cycle in the supply of credit and liquidity and, by extension, in asset prices. On the other hand, better capitalized banks are more resilient and perform better during financial crises (Demirguc- Kunt et al., 2013), suggesting the need to build adequate safeguards in normal times, in the form of additional capital buffers.

Monitoring the course of the credit cycle is key to identifying aggregate credit risk buildup through the economic cycle. Financial cycles are in many ways different from the business cycle, and typically much longer (Claessens et al., 2012, and Drehmann et al., 2012). The aggregate economic losses resulting from a burst of credit and financial cycles are very high - as shown by the Great Depression and the Global Financial Crisis - and trigger much deeper and longer recessions than in usual business cycles, even if monetary policy responds aggressively (Schularick and Taylor, 2012). The subsequent economic recoveries are slower, with long-lasting negative real effects. What's more, while there is plenty of evidence that excessive credit growth often precedes a financial crisis, not all credit booms end this way. Some credit booms are likely to lead to systemic banking crises, others are not, if the boom is part of a normal financial deepening.

A key task for policy makers is to assess the state of the credit and financial cycle and calibrate their macroprudential policies accordingly. Policy makers should evaluate whether any given surge in credit is excessive and requires a policy response to strengthen the resilience of the banking system to a possible systemic crisis. Studies have shown that the credit-to-GDP gap (i.e., the difference between private sector credit-to-GDP ratio and its estimated trend, also referred to as 'credit gap' in the rest of paper) can be a powerful predictor of banking crises (Borio and Drehmann, 2009). The Basel Committee on Banking Supervision (BCBS) has established thresholds for the credit-to-GDP beyond which extra vigilance is required and policy may need to respond by increasing bank capital requirements.

Countercyclical capital buffers can help mitigate risks arising from excessive credit growth and limit the pro-cyclicality of bank lending. The Countercyclical Capital Buffer 
(CCyB) proposed by the BCBS $(2010,2011)$ as part of the Basel III regulatory framework is a time-varying broad-based capital instrument that is designed to achieve the macroprudential goal of protecting the banking sector from the risks arising from excessive aggregate credit growth. Due to its countercyclical nature, the CCyB may also help to counter the pro-cyclicality of the financial system by leaning against the build-up phase of the credit cycle. In downturns, the release of the buffer should help to reduce the risk that the supply of credit is constrained by too tight capital requirements that could drive a crunch in credit supply, undermine the performance of the real economy, and result in additional credit losses in the banking system. The $\mathrm{CCyB}$ ensures therefore that banking sector capital requirements take into account the macro-financial environment in which banks operate.

Decisions on the level of the CCyB should have the credit-to-GDP gap as an anchor but also consider other information. Reliably estimating the credit-to-GDP gap might not be a trivial task, particularly in developing economies. First, credit growth and trend dynamics can be difficult to interpret if financial deepening is underway, as above trend growth might not necessarily signal the build-up of imbalances. Second, the value attached to the credit-to GDP-gap can be heavily constrained if the time series used for its estimation are too short and/or subject to important structural breaks. Hence, the credit gap should be complemented by deeper analysis of the macroeconomic and financial outlook.

In this paper we review the financial and credit developments in CAPDR countries, provide a comparative assessment of the credit cycle in the region, and discusses the possible use of the $\mathrm{CCyB}$ as a tool to enhance the resilience of the banking system. Section II portrays the current state of financial developments in the region. Section III presents the methodology used to estimate the credit-to-GDP gap, starting from the approach proposed by the BCBS, which we adjust to account for the fast credit growth environment of developing economies. Section IV presents the empirical analysis where we estimate the credit gap, test its ability to signal impeding financial distress for each country in the region, and discuss implications for $\mathrm{CCyB}$ setting and capital adequacy. Section V concludes.

\section{Financial MaRkets ANd CREdit In CAPDR}

The financial sectors of CAPDR countries remain relatively shallow and dominated by banks. Credit-to-GDP ratios are low in most countries and banks continue to dominate the financial landscape, providing more than 90 percent of credit to the private sector with wide intermediation spreads. Bank credit-to-GDP ratios range from about 40 percent in the Dominican Republic to about 80 percent in Costa Rica, with Nicaragua, El Salvador, Guatemala, and Honduras in the middle range (Figure 1). Panama is an outlier, with a larger and deeper financial system and lower bank concentration.

Most countries in the region have experienced a prolonged increase in the credit-toGDP ratio over recent years, suggesting an ongoing process of financial deepening. Over the past decade, the bank credit-to-GDP ratio has increased by about 50 percent in Costa Rica, and 40 percent in the Dominican Republic, followed by 35 and 30 percent respectively in Honduras and Nicaragua, while remaining broadly constant in Panama and El Salvador. However, financial deepening did not always imply financial inclusion, especially at the household level, and the financial development does not appear to be fully 
aligned with macroeconomic fundamentals. For example, lower levels of financial development than the one implied by fundamentals reflect a contraction of credit supply following the 2003 financial crisis in the Dominican Republic (Ramírez de León, 2012), and high bank concentration and weak collateral frameworks in Costa Rica and Nicaragua. On the other hand, higher financial development than levels implied by fundamentals in Panama, Honduras, Guatemala and El Salvador captures scant investment opportunities and underdeveloped stock markets that lack adequate legal and contractual infrastructure (Heng et al., 2016).

Banks are currently well capitalized, with good credit quality and a solid deposit base. Banking systems in CAPDR have capital ratios comfortably above minimum requirements, NPLs are low - ranging from about 1 percent of total loans in Nicaragua to about 2.5 percent in Honduras and Guatemala - and typically over-provisioned. Credit is mostly financed by costumer deposits, which account on average for 80 percent of total (non-interbank) loans.

However, the high dollarization of both assets and liabilities creates vulnerabilities. Panama and El Salvador are officially dollarized, and dollarization is very high in Nicaragua (97 and 74 percent of total bank assets and liabilities respectively). Dollarization of assets and liabilities in the rest of the region averages about 30 percent and is relatively higher in Costa Rica and Guatemala, exposing the system to exchange rate and rollover risks. The high share of FX credit granted to borrowers without natural edges (as high as 70 percent in Costa Rica and Nicaragua) compounds these exposures with credit risk in case of sustained exchange rate depreciations.

Since the early 2000s, financial linkages within the region have increased considerably, driven by strengthened economic links. The past decade has seen a rapid expansion of financial conglomerates with cross-border operations in the region, as domestic financial institutions became regional financial conglomerates with complex structures, although the extent of conglomerate presence varies significantly by country (from over 90 percent of total banking assets in El Salvador to a very small presence in the Dominican Republic). While regional financial integration could foster diversification of the domestic financial systems, it also increases the risk of potential cross-border spillovers. Hence, policy coordination and consolidated supervision of cross-border operations are critical to maintain financial stability in the region (IMF, 2016). 


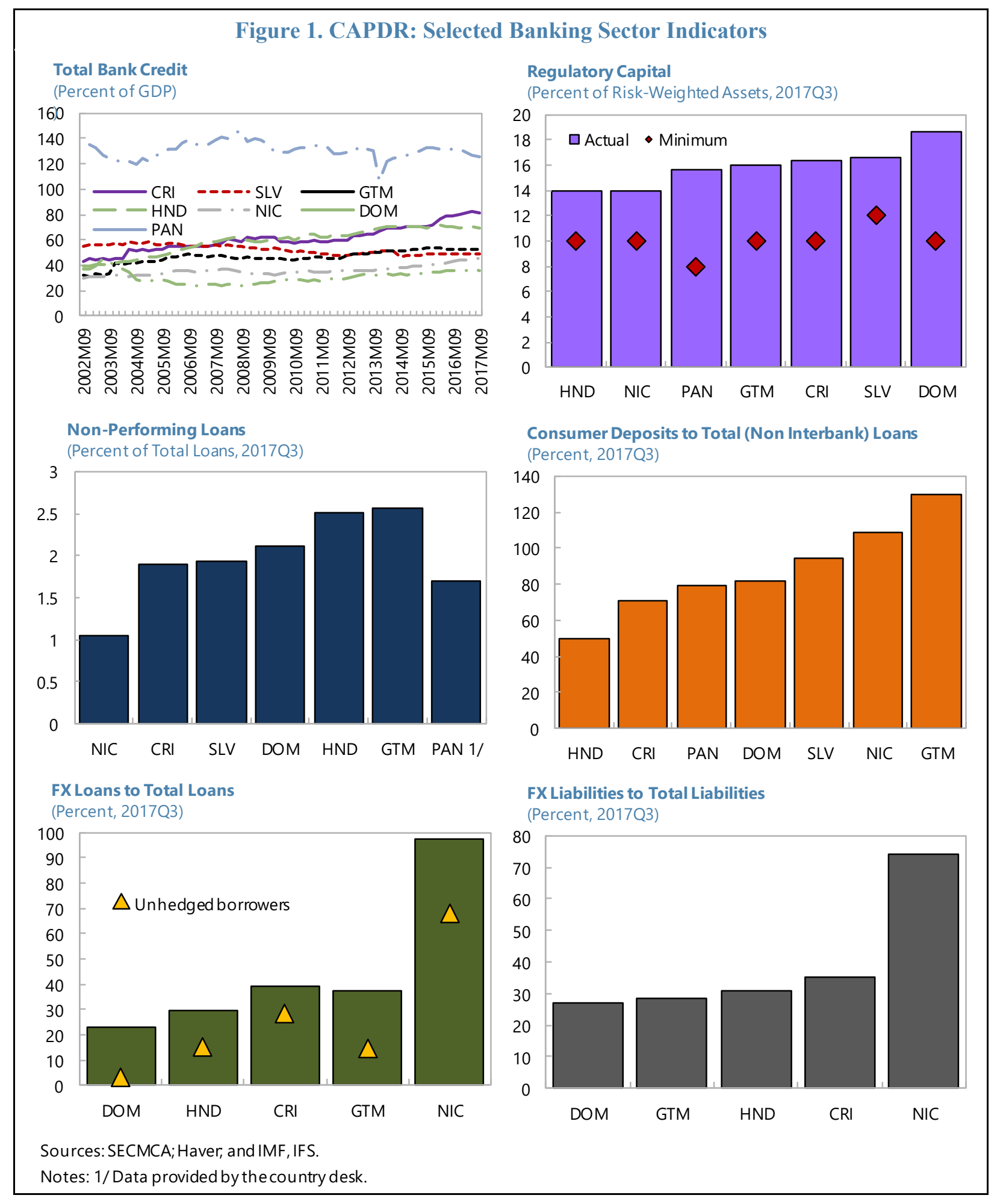




\section{Estimating The Credit CyCle: Methodology ANd Data}

The credit cycle is estimated as the deviation of the credit-to-GDP ratio from its long run trend. This measure has been introduced by the BCBS $(2010,2011)$ as a key reference indicator to calibrate the CCyB mainly because of its out-of-sample forecasting power in predicting banking crises in a large sample of countries. Subsequent research by various authors has largely confirmed the properties of this measure for advanced countries while some have questioned its performance for samples of developing countries.

We use the one-sided backward-looking HP filter to estimate the long-run trend in the credit-to-GDP ratio. The choice of the one-sided HP filter is consistent with the Basel Committee on banking Supervision's guidelines (BCBS, 2010 and 2011) and has the appealing feature of being measurable in real time. ${ }^{2}$ Formally, indicating with $C T G_{t}$ the credit-to-GDP ratio at time $t$, the one-sided HP filter estimates the trend as the solution to the following minimization problem:

$$
\min _{\text {Trend }_{t}} \sum_{t=1}^{T}\left(C T G_{t}-\text { Trend }_{t}\right)^{2}+\lambda \sum_{t=3}^{T}\left(\text { Trend }_{t}-2 \operatorname{Trend}_{t-1}+\operatorname{Trend}_{t-2}\right)^{2}
$$

which balances the trade-off between the size of the estimated cycles and the variation in trend growth rate, with the smoothing parameter $\lambda$ establishing the relative weight of each of the two terms: the larger the smoothing parameter, the more importance is assigned to the second term, and therefore the "smoother" the trend series would be. Since financial cycles are thought to operate at very low frequencies, the smoothing parameter is usually set at large values. BCBS (2010), based on Borio and Lowe (2002), suggests a smoothing parameter of $400000 .^{3}$

Credit in this context is defined as aggregate credit extended to households and nonfinancial private businesses by banks and non-banks. This measure of credit includes all credit that is extended to the private non-financial sector through banks, nonbanks, corporate bond markets, and foreign intermediaries or investors, as such indicator proves to overperform narrower definitions of credit in signaling future banking crises. However, since there is a clear trade-off between length and coverage of the credit series, for our estimates we consider aggregate quarterly data on credit extended by banks (including off-shore banks, and adding cooperatives, and other financial institutions where available) but excluding corporate bonds due to the shorter length of these time series). See Appendix for a description of the data used in the estimates.

\footnotetext{
${ }^{2}$ The reliability of the one-sided HP filtered estimates has however been questioned (among others, Orphanides and van Norden, 2002, and Edge and Meisenzahl, 2011) and some studies have proposed ways to address this problem in the context of the credit-to-GDP gap (Alessandri et al, 2015).

${ }^{3}$ This value should be compared to 1600 , which is the value of the smoothing parameter used for estimating business cycles. The difference between the two reflects the idea that financial cycles are thought to be 4-5 times longer than business cycles.
} 
Possible drawbacks related to this methodology apply to CAPDR as to other emerging countries. Chief among them are issues regarding the length of the available data (as noted above) and the presence of structural breaks in the series. Besides the ongoing financial deepening process in CAPDR, shifts in exchange rate policies during the period in consideration also introduce structural breaks in the credit series given the high level of credit dollarization in the economy.

- Length of the time series. Edge and Meisenzahl (2011) argue that the backward-looking nature of the one-sided HP filter puts too much emphasis on the end points and therefore the estimated trend depends heavily on the most recent observations. ${ }^{4} \mathrm{As}$ noted by Gersl and Seidler (2012), the estimated trend changes very significantly with the starting point of the series, Drehmann and Tsatsaronis (2014) and Alessandri and others (2015) shows that this problem gets much worse as the length of available time series shrinks. Both drawbacks suggest that the longest available time series should be used to attain the best possible estimation of the credit gap. Borio and Lowe (2002) suggest that this calculation should not be done for time series with length of less than 10 years at least, while many others suggest 20 years of data is the minimum requirement.

- Structural breaks. The use of such credit gap measures may hinder the process of beneficial financial deepening undergone by many emerging market economies (Reserve Bank of India, 2013), because this measure essentially penalizes fast growth rates of credit-to-GDP, which could be a structurally desirable and positive outcome. This also induces a reverse problem: a sustained period of high growth in credit-toGDP ratio translates to a faster trend growth estimate which could turn CCyB measures never binding. BCBS (2010) and BCBS (2011) recognize these issues and the limited information contained in the one-sided HP filtered credit gap and recommend using additional variables to guide the decision regarding $\mathrm{CCyB}$ rates.

Since the usual credit gap measure is inconsistent with sustained fast credit growth, we consider a normalized indicator to reflect ongoing financial deepening in the region. The standard credit-to-GDP gap proposed by the BCBS is based on studies of countries with high levels of financial deepening, mostly with credit-to-GDP ratios above 100 percent (Drehmann et al., 2011). For countries with lower level of financial deepening such as in CAPDR, which has credit-to-GDP ratios averaging 65 percent, the standard credit gap might not be the most appropriate measure to capture the evolution of the credit cycle. As an alternative, a percentage deviation of the credit gap relative to the trend of the credit-to-GDP ratio is proposed. ${ }^{5}$ Hence the normalized credit gap is defined as:

\footnotetext{
${ }^{4}$ As shown by Orphanides and van Norden (2002).

${ }^{5}$ The motivation for the alternative measure can be better understood by going through an example. Consider two countries with different levels of financial deepening: country A with a credit-to-GDP ratio of 30 percent and a trend value of 20 percent, and country B with a credit-to-GDP ratio of 110 percent and a trend value of 100 percent. Per the
}

(continued...) 


$$
(\text { Cre } \widehat{\operatorname{dit} G} a p)_{t}=\frac{C T G_{t}-\text { Trend }_{t}}{\text { Trend }_{t}}
$$

We calibrate the CCyB based on the estimated credit cycle, following the Basel III framework. According to the Basel III guidelines, the CCyB varies between zero and 2.5 percent of risk-weighted assets: authorities should increase the rate when risks associated with excessive credit growth build-up, and should lower it when risks materialize to sustain the flow of credit to households and corporations and contain the risk of systemic deleverage. Policy makers are expected to apply judgment in setting the buffer in their jurisdiction after using the best information available to gauge the build-up of system-wide risk.

\begin{abstract}
Additional signals of financial risk build-up include measures of excessive credit growth, lenient credit risk pricing, and measures of high leverage. In contrast to credit gap, however, there are no specific definitional or numerical recommendations for these measures by BCBS.
\end{abstract}

\title{
IV. Where Do CAPDR Countries Stand In THE CREDit CyCLE?
}

Credit in the CAPDR countries is recovering after the large contraction experienced during the global financial crisis. Figure 2 shows credit cycles for each CAPDR country since the early 1990s. Several countries experienced credit booms between 2003 and 2007, followed by a severe credit crunch during the global financial crisis (GFC). Since the end of the GFC credit growth has recovered across the region, and most CAPDR countries' credit cycles are in an expansionary phase of the credit cycle since 2013 with the exception of one country where credit growth has been growing at trend (Costa Rica) and two countries (Guatemala and Honduras) with credit growth slightly below trend.

BCBS standard approach, both countries have a credit gap of 10 percentage points. However, for country A to reach a credit-to-GDP ratio of 30 percent credit must grow about 50 percent faster than GDP, while in country B credit has to grow only about 10 percent faster than GDP. If one thinks that a constant fraction of the new credit extended above the trend value (10 percentage points in the case of country B) is excessive and increases systemic vulnerability, the increase in capital and loss absorbing capacity in country A should be much larger than that of country B, i.e., around 5 times larger. Using the percentage deviation of credit gap from the trend averts this issue. 


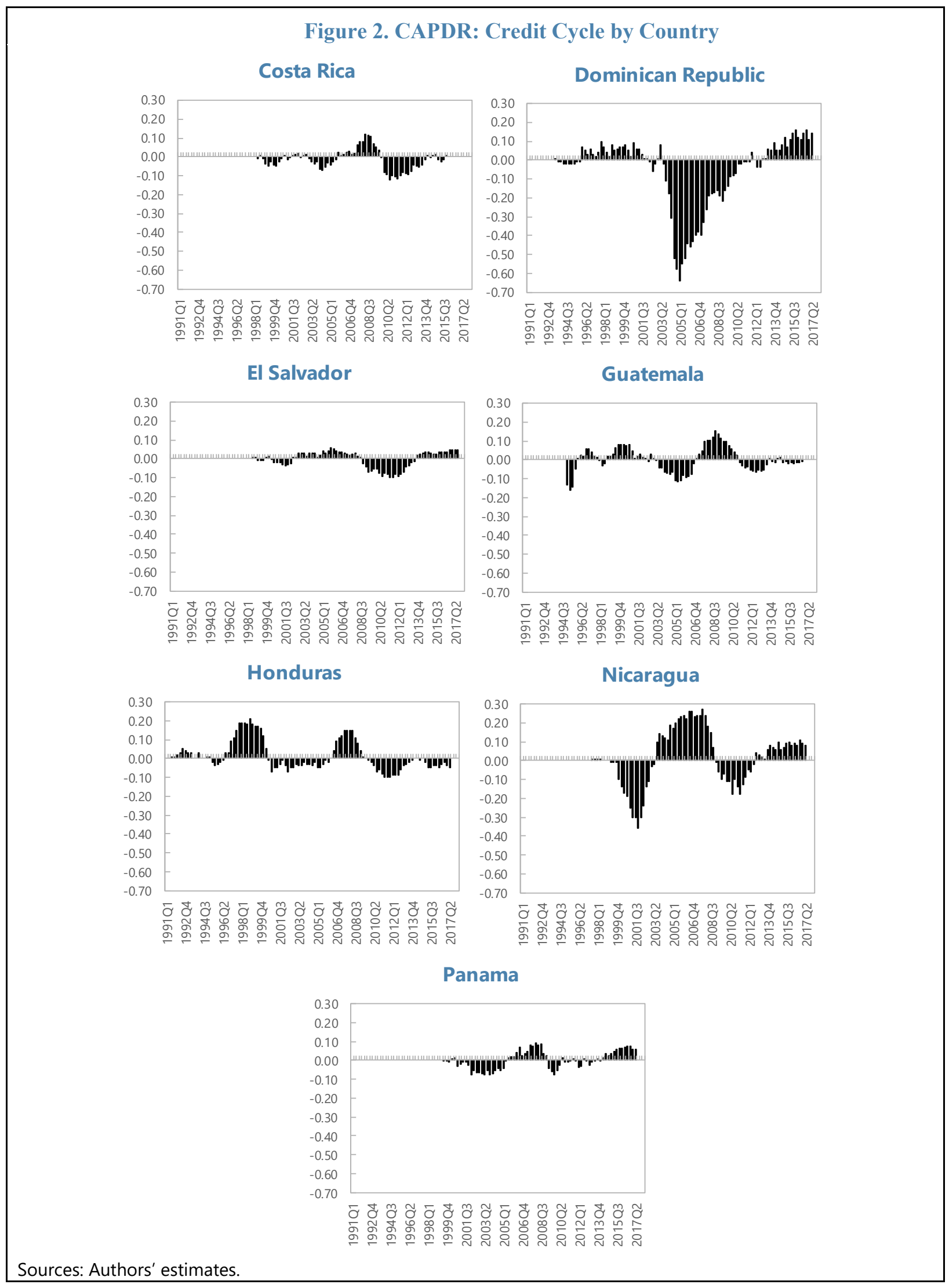


We compare CAPDR countries' credit cycles by constructing measures based on the business cycles literature. Following Mink et al. (2012) and Samarina et al. (2015) we focus on two dimensions of the credit cycles: (i) synchronicity to compare the direction (or correlation) of credit cycles among countries, and (ii) similarity to compare the magnitude (or dispersion) of the countries' credit cycles.

Let $c_{i}(t)$ be the credit gap of country $i$ in period $t$, and let $c_{r}(t)$ be the credit gap of the CAPDR region at time $t$, calculated as the median credit gap for all CAPDR countries. Synchronicity between country $i$ and the CAPDR credit cycle at time $t$ is defined as:

$$
\rho_{i}(t)=\frac{c_{i}(t) c_{r}(t)}{\left|c_{i}(t) c_{r}(t)\right|}
$$

The country synchronicity index is defined in the interval $[-1,1]$ and assumes value 1 if the credit cycle of country $i$ moves according to the same direction of the CAPDR credit cycle (the two credit gaps have the same sign) and -1 otherwise.

The CAPDR synchronicity cycle for the 7 members of the region can be defined as the average of the synchronicity indexes for each country $i$ at each time $t$ :

$$
\rho_{i}(t)=\frac{1}{n} \sum_{i=1}^{n} \frac{c_{i}(t) c_{r}(t)}{\left|c_{i}(t) c_{r}(t)\right|}
$$

The CAPDR synchronicity index is defined on the interval [0,1]. It assumes value 1 when all countries credit cycles' move in the same direction of the CAPDR credit cycle (perfect synchronization) and 0 when only half of the countries' credit cycles move in the same direction.

Credit cycle similarity is defined as the difference in credit cycle amplitude between country $i$ and CAPDR credit gaps:

$$
\pi_{i}(t)=1-\frac{\left|c_{i}(t)-c_{r}(t)\right|}{\frac{1}{n} \sum_{i=1}^{n}\left|c_{i}(t)\right|}
$$

The index is defined on the interval [1-n,1], with 1 corresponding to the case of identical amplitude and synchronization of each country credit cycle. The CAPDR region wide similarity index can be defined as:

$$
\pi(t)=1-\frac{\sum_{i=1}^{n}\left|c_{i}(t)-c_{r}(t)\right|}{\sum_{i=1}^{n}\left|c_{i}(t)\right|}
$$

The index is defined on the interval $[0,1]$. Higher values indicate that the amplitudes of the countries' credit cycles are very similar to those of the CAPDR cycle. 
The credit cycles of CAPDR countries are somewhat heterogenous. Table 1 shows the averages of the synchronicity and similarity indexes over the period 1998-2017 with respect to the CAPDR regional cycle. Most countries' credit cycles move in the same direction of the CAPDR reference cycle most of the time since the average synchronicity index is above 0.5 for most of the countries. However, we observe some notable exceptions. The credit cycle of the Dominican Republic is desynchronized with respect to the regional cycle due the recovering from the 2003 crisis that prevented credit accumulation in the run-up to the GFC, and monetary policy measures aimed at influencing credit dynamics in response to idiosyncratic shocks. Moreover, Guatemala and to a less extent Costa Rica's credit cycles are less synchronized with the CAPDR region. In contrast, the El Salvador's credit cycle is very synchronized with the regional credit cycle, followed by Honduras, Nicaragua and Panama which have synchronicity indexes slightly above 0.5 . The credit cycles of the CAPDR countries could also be compared with respect to the amplitude of the credit gaps (similarity). According to this index, Panama's credit cycle is the most "similar" to the region reference cycle, while the Dominican Republic's credit cycle is the most dissimilar. Moreover, notwithstanding the high synchronization of the Nicaragua's credit cycle with the reference CAPDR credit cycle, the amplitude of its credit gaps is significantly larger than the regional average (Table 1).

\begin{tabular}{|lcc|}
\hline & Table 1. CAPDR: Synchronicity and Amplitude of Credit Cycles \\
\hline Country & Synchronicity & Similarity \\
Costa Rica & 0.46 & 0.53 \\
Dom. Republic & 0.22 & -0.64 \\
El Salvador & 0.76 & 0.60 \\
Guatemala & 0.39 & 0.46 \\
Honduras & 0.53 & 0.13 \\
Nicaragua & 0.53 & -0.37 \\
Panama & 0.53 & 0.71 \\
CAPDR & 0.50 & 0.20 \\
\hline Source: Authors' estimates. & & \\
\hline
\end{tabular}

The synchronicity and similarity indexes of the CAPDR credit cycle are countercyclical. Synchronicity increased during contractionary phases of the business cycles, but it declined during booms over the last 20 years (Figure 3 ). The region-wide credit cycle is more synchronized in 1998 and from 2007 to 2011. After a significant drop in the early 2000, synchronicity slowly increased reaching a maximum of 0.94 during the years of the GFC. Likewise, the amplitude of the countries' credit gaps, measured by the similarity index, increased from the late $90 \mathrm{~s}$ and reached its peak during the years of the global financial crisis.

Regional financial integration positively contributes to the coherence of credit cycles in the CAPDR region. The increase in synchronicity and amplitude of the CAPDR countries' credit cycles during the global financial crisis suggests that financial integration plays a prominent role in the coherence of the credit cycles across the region. Financial integration can be of two types: capital market integration (equity and FDI) and credit market integration (debt). Capital market integration in the region leads to negative output correlation as capital 
moves towards countries with higher marginal return as predicted by the real business cycle literature. However, credit market integration through the presence of regional bank conglomerates contributes positively to credit cycles' coherence in the presence of financial shocks due to banks' de-risking. The literature is ambivalent on the impact of financial integration on the coherence of credit cycles across countries depending on the prevailing effect of financial markets' integration. However, Scott (2009) shows that the credit cycles of financially integrated regions become more similar during economic downturns since the financial contagion effect (Allen and Gale, 2000) prevails on the capital market integration effect owed to the rapid propagation of financial shocks through the regional banking system.

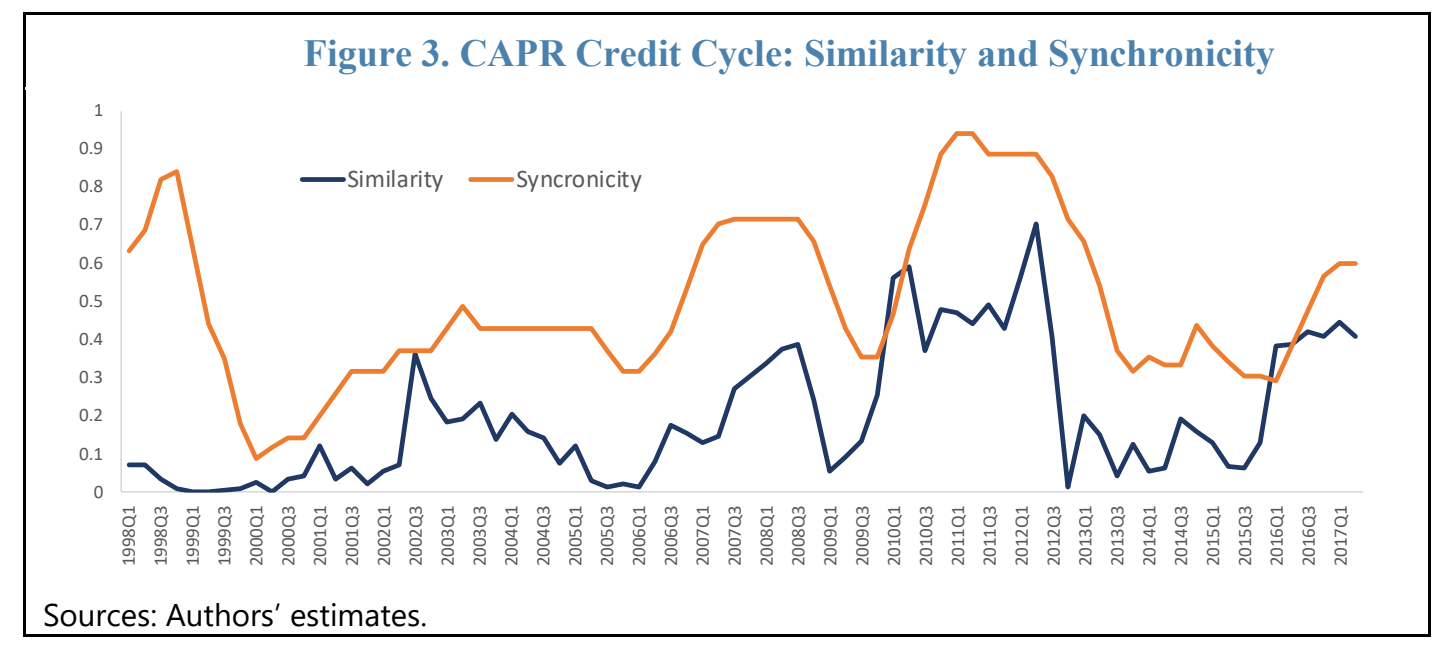

\section{Early Warning Power of the Credit-to-GDP GaP}

We assess the early warning properties of the credit-to-GDP gap to evaluate its value to inform macroprudential policy decision. As most CAPDR countries, except for Nicaragua in 2000 and the Dominican Republic in 2003, have not experienced any episode of banking crisis in recent decades, we use the annual change in the NPL ratio as a measure of financial distress. The unavailability of crisis episodes against which to assess the early warning properties of the credit gap is not a limitation per se. In fact, the CCyB should be high whenever systemic risk is high, irrespective of whether or not an actual crisis materializes. This makes to some extent even more appropriate using a continuous risk measure (such as the change in NPL) instead of a binary crisis variable to assess the properties of the credit gap. The power of the indicator is evaluated at 1 and 2-year horizons. The analysis is carried out with a simple regression on quarterly data, first using the credit gap as the only regressor and then augmenting the model with additional macro variables, namely yearly GDP growth rate, consumer price inflation, and annual change in the current account balance-to-GDP ratio. ${ }^{6}$ The time sample varies by country depending on data availability (see Appendix).

\footnotetext{
${ }^{6}$ The regressions presented here aim at exploring the early warning power of the credit-to-GDP gap and are not meant to provide a full assessment of the determinants of NPL growth. For this reason, they do not include some of the regressors included in the relevant literature on the determinants of NPL (see, among others, Ghosh (2015) for a study of NPLs determinants).
} 
Results from the univariate model indicate that the credit-to-GDP gap is a powerful predictor of future financial distress in CAPDR countries. This evidence is confirmed for Costa Rica, Dominican Republic, Guatemala, and Honduras at both 1 and 2-years horizons, for El Salvador and Nicaragua at the 2-years horizon, and for Panama at the 1-year horizon. (Table 2). Overall the results show that the credit-to-GDP gap has its maximum predictive power for the 2-year horizon for all countries except Panama, even though for Honduras only in economic terms (as the 2-years predictions is slightly less significant relative to the 1-year).

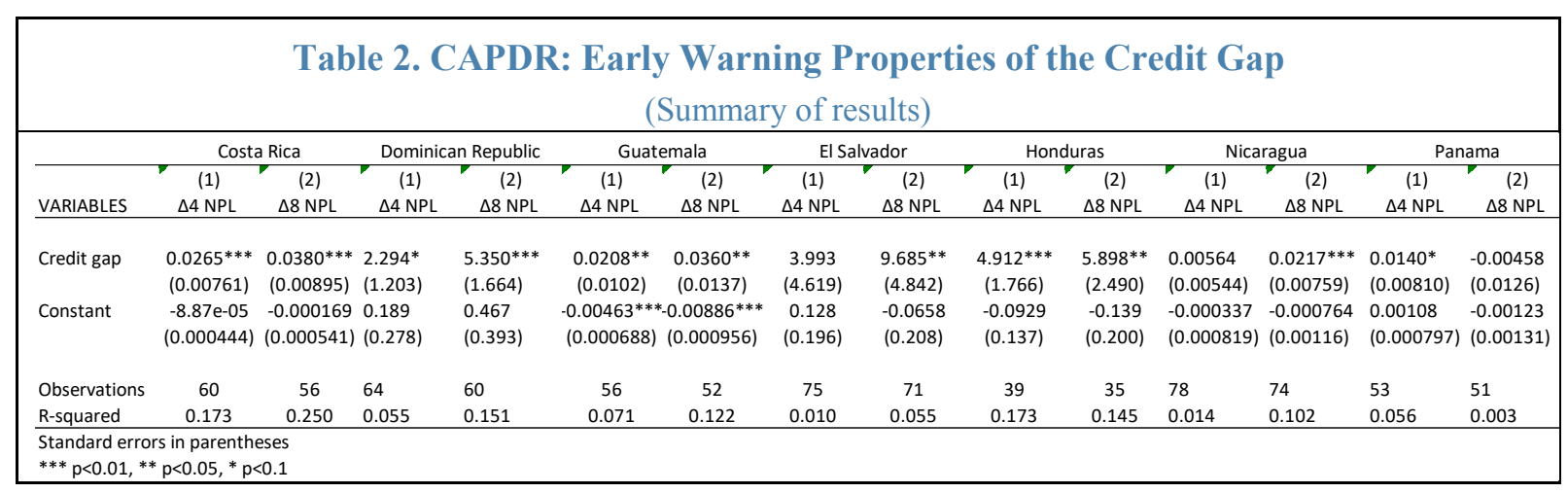

The augmented model confirms the early warning power of the credit gap even when controlling for other macro indicators. The credit gap retains its significance for most of the countries, particularly for the 2-years prediction horizon, except in Guatemala and Honduras, where the credit-gap loses its significance by adding the macroeconomic variables (Table 3, sub (1), (3), (7), and (8)). Results also show that GDP growth and inflation could also contribute to explain future NPL changes for most of the countries. In particular, GDP growth is significant for the 2-year horizon for Costa Rica, Dominican Republic, Honduras, El Salvador and marginally for Nicaragua. For El Salvador significance is observed also for the 1-year horizon. Inflation is significant for Costa Rica (in the 2-year horizon estimation), El Salvador (in the 1- and 2-year horizon estimations) and Honduras (in the 1-year horizon estimation). In the case of Costa Rica also the change in the current account to GDP ratio is significant in the 8 quarters ahead estimation. In the case of Guatemala only none of the variables is significant.

The results are however not fully consistent across countries. GDP growth has a positive sign for the 2-years forecasting horizon for Costa Rica, Dominican Republic and Honduras, but it has a negative sign for both the 1- and the 2-years horizons for El Salvador and for the 2 -years horizon for Nicaragua (although only marginally). Inflation is positive for El Salvador (for both the 1- and 2-years estimation horizon) and for Honduras (for the 1-year horizon) but it is negative for Costa Rica (for the 2-year horizon). The positive sign of GDP growth over the 2-year horizon (the most robust result across the CAPDR) could be interpreted as an indication that higher economic activity could be symptomatic of a slowdown two years ahead, which could in turn imply a deterioration of credit worthiness of economic agents. The positive sign of inflation rate speaks toward the same interpretation, i.e. an overheating economic activity signaling a forthcoming slowdown and hence increase in NPLs. Under this reasoning the interpretation of the negative sign of inflation for Costa 
Rica and of GDP for El Salvador becomes problematic. However, it is also worth noting that, if taken in isolation, a negative sign of GDP growth would seem the most intuitive result, i.e. negative change in GDP growth leading to higher NPL 1 and 2 years in the future.

Credit growth is also found to play a role in predicting financial distress. Computing a 2-year growth amounts to smoothing the credit dynamics series in a way that is not conceptually different from using the HP filter with a high value of the lambda parameter (as the one we used). When we replace the credit gap with the 2-year credit growth as predictor of the change in NPL we find results similar to those obtained with the credit gap, confirming the important role played by the credit variables in the financial cycle (Table 3, sub (2),(4), (5), and (6)).

\begin{tabular}{|c|c|c|c|c|c|c|c|c|}
\hline \multicolumn{9}{|c|}{$\begin{array}{l}\text { Table 3. CAPDR: Early Warning Properties of the Credit Gap } \\
\text { (Country specific results) }\end{array}$} \\
\hline \multicolumn{9}{|l|}{ COSTA RICA } \\
\hline VARI ABLES & $\begin{array}{c}(1) \\
\triangle 4 \mathrm{NPL} \\
\end{array}$ & $\begin{array}{c}(2) \\
\triangle 4 \mathrm{NPL} \\
\end{array}$ & $\begin{array}{c}(3) \\
\Delta 8 \mathrm{NPL}\end{array}$ & $\begin{array}{c}(4) \\
\triangle 8 \mathrm{NPL}\end{array}$ & $\begin{array}{c}(5) \\
\triangle 4 \mathrm{NPL}\end{array}$ & $\begin{array}{c}(6) \\
\Delta 8 \mathrm{NPL}\end{array}$ & $\begin{array}{c}(7) \\
\triangle 4 \mathrm{NPL} \\
\end{array}$ & $\begin{array}{c}(8) \\
\triangle 8 \mathrm{NPL}\end{array}$ \\
\hline Credit growth_2y & & $\begin{array}{l}0.000159^{*} \\
(9.32 \mathrm{e}-05)\end{array}$ & & $\begin{array}{c}0.000167 \\
(0.000117)\end{array}$ & $\begin{array}{l}0.000100 \\
(9.46 \mathrm{e}-05)\end{array}$ & $\begin{array}{c}9.10 \mathrm{e}-05 \\
(0.000110)\end{array}$ & & \\
\hline GDP growth & & & & & $\begin{array}{c}-0.000747 \\
(0.0127)\end{array}$ & $\begin{array}{l}0.0316^{* *} \\
(0.0148)\end{array}$ & $\begin{array}{c}0.000733 \\
(0.0123)\end{array}$ & $\begin{array}{l}0.0327 * * \\
(0.0128)\end{array}$ \\
\hline CPI inflation & & & & & $\begin{array}{c}0.0276 \\
(0.0179)\end{array}$ & $\begin{array}{r}-0.00300 \\
(0.0214)\end{array}$ & $\begin{array}{c}0.0108 \\
(0.0191)\end{array}$ & $\begin{array}{c}-0.0465^{* *} \\
(0.0217)\end{array}$ \\
\hline $\mathrm{CA} / \mathrm{GDP}$ & & & & & $\begin{array}{l}-0.0446 \\
(0.0281)\end{array}$ & $\begin{array}{l}-0.0850^{* *} \\
(0.0333)\end{array}$ & $\begin{array}{l}-0.0357 \\
(0.0271)\end{array}$ & $\begin{array}{c}-0.0673^{* *} \\
(0.0288)\end{array}$ \\
\hline Credit gap & $\begin{array}{l}0.0265^{* * *} \\
(0.00761)\end{array}$ & & $\begin{array}{l}0.0380^{* * *} \\
(0.00895)\end{array}$ & & & & $\begin{array}{l}0.0214^{* *} \\
(0.00923)\end{array}$ & $\begin{array}{c}0.0412^{* * *} \\
(0.0103)\end{array}$ \\
\hline Constant & $\begin{array}{l}-8.87 \mathrm{e}-05 \\
(0.000444)\end{array}$ & $\begin{array}{l}-0.000558 \\
(0.000464)\end{array}$ & $\begin{array}{r}-0.000169 \\
(0.000541)\end{array}$ & $\begin{array}{l}-0.000770 \\
(0.000603)\end{array}$ & $\begin{array}{c}-0.00488^{* *} \\
(0.00193)\end{array}$ & $\begin{array}{c}-0.00859 * * * \\
(0.00231)\end{array}$ & $\begin{array}{l}-0.00280 \\
(0.00213)\end{array}$ & $\begin{array}{l}-0.00332 \\
(0.00242)\end{array}$ \\
\hline $\begin{array}{l}\text { Observations } \\
\text { R-squared }\end{array}$ & $\begin{array}{c}60 \\
0.173\end{array}$ & $\begin{array}{c}59 \\
0.049\end{array}$ & $\begin{array}{c}56 \\
0.250\end{array}$ & $\begin{array}{c}55 \\
0.037\end{array}$ & $\begin{array}{c}59 \\
0.142\end{array}$ & $\begin{array}{c}55 \\
0.260\end{array}$ & $\begin{array}{c}60 \\
0.203\end{array}$ & $\begin{array}{c}56 \\
0.429\end{array}$ \\
\hline \multicolumn{9}{|c|}{$\begin{array}{l}\text { Standard errors in parenthes es } \\
{ }^{* * *} p<0.01,{ }^{* *} p<0.05,{ }^{*} p<0.1\end{array}$} \\
\hline \multicolumn{9}{|c|}{ DOMINICAN REPUBLIC } \\
\hline VARIABLES & $\begin{array}{c}(1) \\
\Delta 4 \mathrm{NPL} \\
\end{array}$ & $\begin{array}{c}(2) \\
\Delta 4 \mathrm{NPL} \\
\end{array}$ & $\begin{array}{c}(3) \\
\triangle 8 \mathrm{NPL} \\
\end{array}$ & $\begin{array}{c}(4) \\
\triangle 8 \mathrm{NPL} \\
\end{array}$ & $\begin{array}{c}5) \\
\Delta 4 \mathrm{NPL} \\
\end{array}$ & $\begin{array}{c}6) \\
\triangle 8 \mathrm{NPL} \\
\end{array}$ & $\begin{array}{c}\text { (7) } \\
\triangle 4 \mathrm{NPL} \\
\end{array}$ & $\begin{array}{c}(8) \\
\Delta 8 \mathrm{NPL} \\
\end{array}$ \\
\hline Credit growth_2y & & $\begin{array}{l}3.197^{*} \\
(1.671)\end{array}$ & & $\begin{array}{c}8.704^{* * *} \\
(2.110)\end{array}$ & $\begin{array}{c}7.570^{* * *} \\
(0.689)\end{array}$ & $\begin{array}{c}7.327^{* * *} \\
(1.766)\end{array}$ & & \\
\hline GDP growth & & & & & $\begin{array}{l}2.136 \\
(2.470)\end{array}$ & $\begin{array}{l}14.69 * * \\
(5.703)\end{array}$ & $\begin{array}{l}8.548 \\
(6.052)\end{array}$ & $\begin{array}{l}18.78^{* *} \\
(6.885)\end{array}$ \\
\hline CPI inflation & & & & & $\begin{array}{l}-2.052 \\
(1.792)\end{array}$ & $\begin{array}{c}-15.40 * * * \\
(4.348)\end{array}$ & $\begin{array}{l}4.427 \\
(5.974)\end{array}$ & $\begin{array}{l}-3.349 \\
(6.711)\end{array}$ \\
\hline $\mathrm{CA} / \mathrm{GDP}$ & & & & & $\begin{array}{c}0.0115 \\
(0.0156)\end{array}$ & $\begin{array}{c}0.0292 \\
(0.0365)\end{array}$ & $\begin{array}{c}0.0427 \\
(0.0394)\end{array}$ & $\begin{array}{c}0.0704 \\
(0.0444)\end{array}$ \\
\hline Credit gap & $\begin{array}{l}2.294^{*} \\
(1.203)\end{array}$ & & $\begin{array}{c}5.350^{* * *} \\
(1.664)\end{array}$ & & & & $\begin{array}{l}4.381^{*} \\
(2.237)\end{array}$ & $\begin{array}{l}7.210^{* *} \\
(2.939)\end{array}$ \\
\hline Constant & $\begin{array}{c}0.189 \\
(0.278)\end{array}$ & $\begin{array}{l}-1.069^{*} \\
(0.588)\end{array}$ & $\begin{array}{c}0.467 \\
(0.393)\end{array}$ & $\begin{array}{c}-2.938^{* * *} \\
(0.744)\end{array}$ & $\begin{array}{c}-2.552^{* * *} \\
(0.223)\end{array}$ & $\begin{array}{c}-3.326^{* * *} \\
(0.503)\end{array}$ & $\begin{array}{c}-1.376^{* * *} \\
(0.474)\end{array}$ & $\begin{array}{c}-2.423 * * * \\
(0.534)\end{array}$ \\
\hline $\begin{array}{l}\text { Observations } \\
\text { R-squared }\end{array}$ & $\begin{array}{c}64 \\
0.055\end{array}$ & $\begin{array}{c}64 \\
0.056\end{array}$ & $\begin{array}{c}60 \\
0.151\end{array}$ & $\begin{array}{c}60 \\
0.227\end{array}$ & $\begin{array}{c}23 \\
0.894\end{array}$ & $\begin{array}{c}19 \\
0.764\end{array}$ & 23 & $\begin{array}{c}19 \\
0.632\end{array}$ \\
\hline $\begin{array}{l}\text { R-squared } \\
\text { Standard errors in } \\
* * * p<0.01, * * p<0\end{array}$ & $\begin{array}{l}0.055 \\
\text { parentheses } \\
05, * p<0.1\end{array}$ & 0.056 & 0.151 & 0.227 & 0.894 & 0.164 & 0.325 & 0.632 \\
\hline
\end{tabular}


Table 3. CAPDR: Early Warning Properties of the Credit Gap (cont'd)

(Country specific results)

\section{EL SALVADOR}

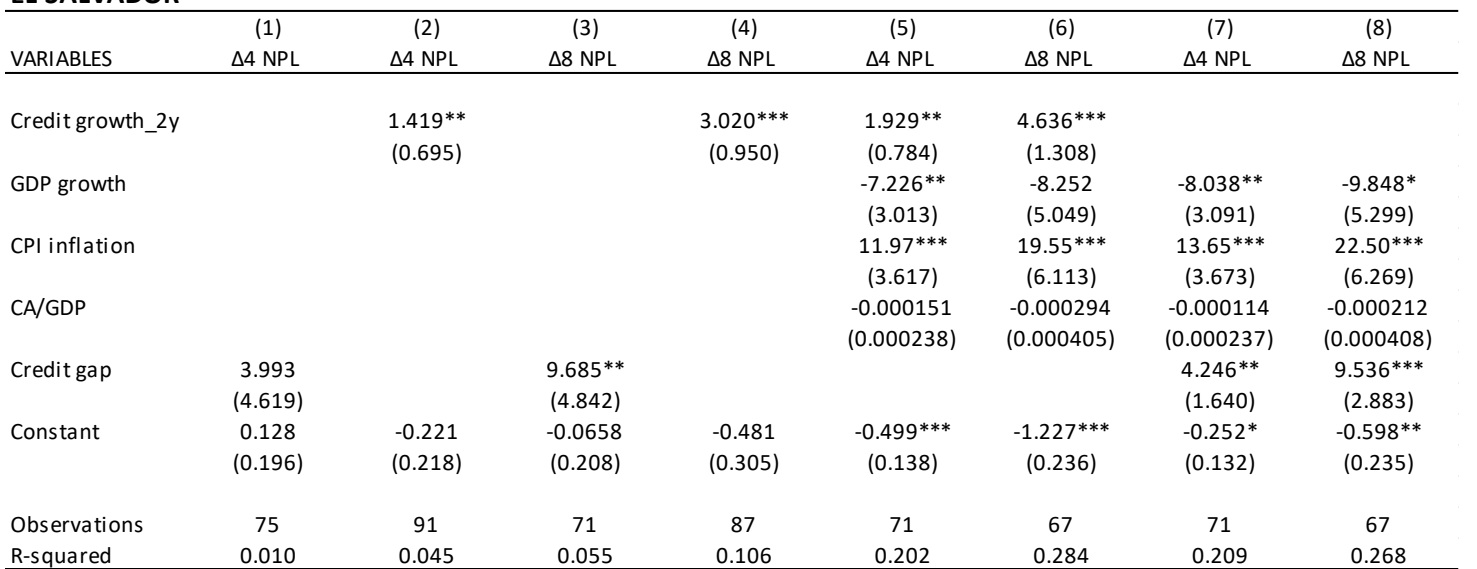

Standard errors in parentheses

*** $p<0.01,{ }^{* *} p<0.05, * p<0.1$

GUATEMALA

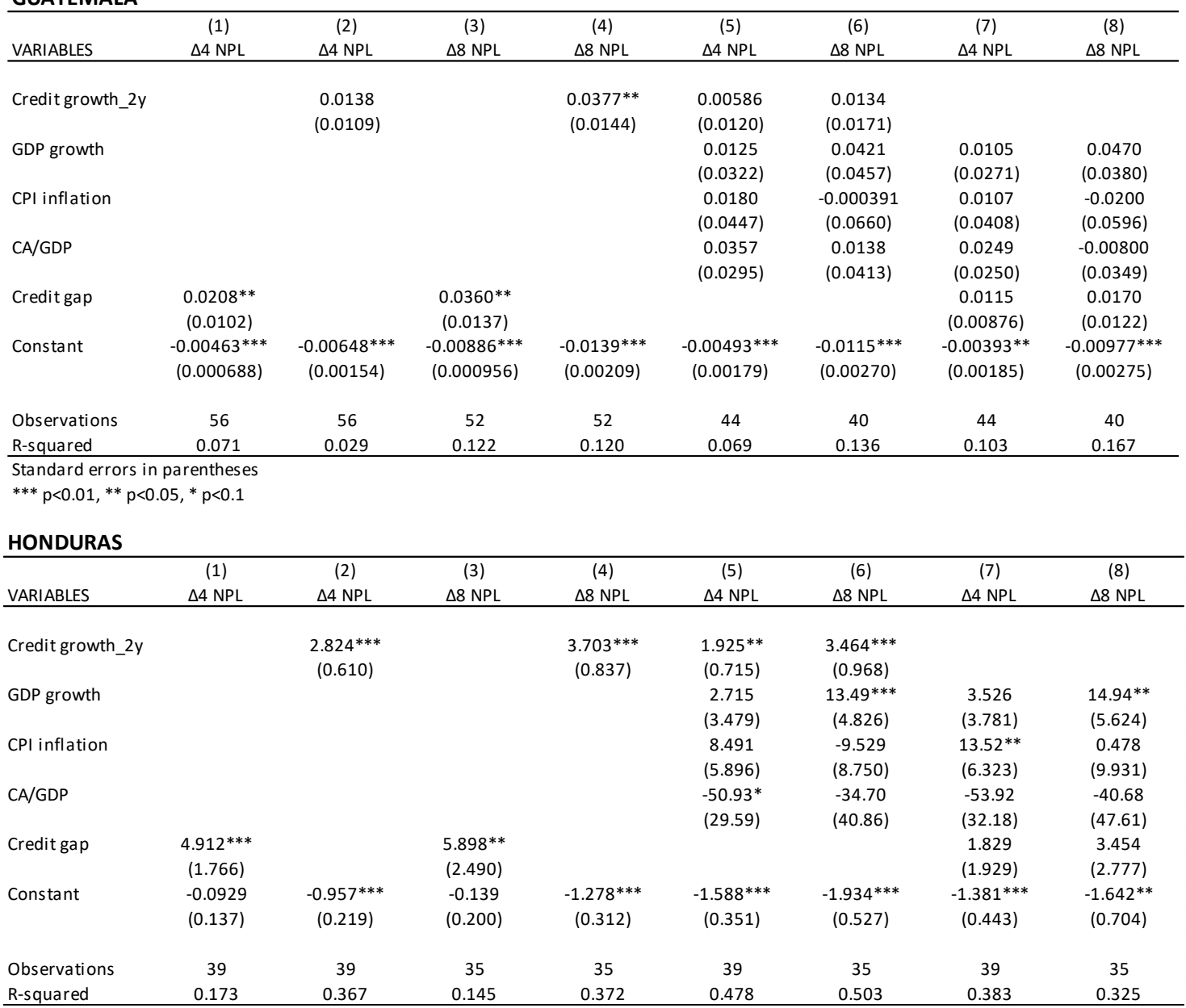

Standard errors in parentheses

$* * * p<0.01, * * p<0.05, * p<0.1$ 


\begin{tabular}{|c|c|c|c|c|c|c|c|c|}
\hline \\
\hline \multicolumn{9}{|l|}{ NICARAGUA } \\
\hline VARIABLES & $\begin{array}{c}(1) \\
\Delta 4 \mathrm{NPL} \\
\end{array}$ & $\begin{array}{c}(2) \\
\triangle 4 \mathrm{NPL} \\
\end{array}$ & $\begin{array}{c}\text { (3) } \\
\triangle 8 \mathrm{NPL} \\
\end{array}$ & $\begin{array}{c}(4) \\
\triangle 8 \mathrm{NPL} \\
\end{array}$ & $\begin{array}{c}(5) \\
\triangle 4 \mathrm{NPL} \\
\end{array}$ & $\begin{array}{c}(6) \\
\Delta 8 \mathrm{NPL} \\
\end{array}$ & $\begin{array}{c}(7) \\
\triangle 4 \mathrm{NPL} \\
\end{array}$ & $\begin{array}{c}(8) \\
\triangle 8 \mathrm{NPL} \\
\end{array}$ \\
\hline Credit growth_2y & & $\begin{array}{c}0.00114 \\
(0.00253)\end{array}$ & & $\begin{array}{l}0.0107^{* * *} \\
(0.00350)\end{array}$ & $\begin{array}{c}0.00282 \\
(0.00502)\end{array}$ & $\begin{array}{l}0.0139 * * \\
(0.00545)\end{array}$ & & \\
\hline GDP growth & & & & & $\begin{array}{l}0.00341 \\
(0.0247)\end{array}$ & $\begin{array}{l}-0.0485^{*} \\
(0.0266)\end{array}$ & $\begin{array}{l}0.00268 \\
(0.0207)\end{array}$ & $\begin{array}{l}-0.0345^{*} \\
(0.0172)\end{array}$ \\
\hline CPI inflation & & & & & $\begin{array}{c}0.0286 \\
(0.0293)\end{array}$ & $\begin{array}{l}0.0712^{* *} \\
(0.0331)\end{array}$ & $\begin{array}{r}-0.00475 \\
(0.0271)\end{array}$ & $\begin{array}{l}0.00339 \\
(0.0243)\end{array}$ \\
\hline $\mathrm{CA} / \mathrm{GDP}$ & & & & & $\begin{array}{l}0.548 \\
(2.317)\end{array}$ & $\begin{array}{l}5.271^{* *} \\
(2.508)\end{array}$ & $\begin{array}{l}-2.312 \\
(2.127)\end{array}$ & $\begin{array}{c}0.899 \\
(1.800)\end{array}$ \\
\hline Credit gap & $\begin{array}{c}0.00564 \\
(0.00544)\end{array}$ & & $\begin{array}{l}0.0217^{* * * *} \\
(0.00759)\end{array}$ & & & & $\begin{array}{l}0.0309 * * * \\
(0.00868)\end{array}$ & $\begin{array}{l}0.0562^{* * *} \\
(0.00752)\end{array}$ \\
\hline Constant & $\begin{array}{l}-0.000337 \\
(0.000819)\end{array}$ & $\begin{array}{l}-0.000740 \\
(0.00135)\end{array}$ & $\begin{array}{l}-0.000764 \\
(0.00116)\end{array}$ & $\begin{array}{l}-0.00527 * * * \\
(0.00187)\end{array}$ & $\begin{array}{l}-0.00470 \\
(0.00299)\end{array}$ & $\begin{array}{c}-0.00822^{* *} \\
(0.00325)\end{array}$ & $\begin{array}{l}-0.00212 \\
(0.00254)\end{array}$ & $\begin{array}{l}-0.00106 \\
(0.00220)\end{array}$ \\
\hline Observations & 78 & 74 & 74 & 70 & 42 & 38 & 42 & 38 \\
\hline R-squared & 0.014 & 0.003 & 0.102 & 0.122 & 0.065 & 0.396 & 0.297 & 0.732 \\
\hline \multicolumn{9}{|c|}{$\begin{array}{l}\text { Standard errors in parentheses } \\
{ }_{* * *} p<0.01, * * p<0.05,{ }^{*} p<0.1\end{array}$} \\
\hline \multicolumn{9}{|l|}{ PANAMA } \\
\hline & (1) & (2) & (3) & (4) & (5) & (6) & (7) & (8) \\
\hline VARIABLES & $\Delta 4 \mathrm{NPL}$ & $\triangle 4 \mathrm{NPL}$ & $\triangle 8 \mathrm{NPL}$ & $\triangle 8 \mathrm{NPL}$ & $\triangle 4 \mathrm{NPL}$ & $\triangle 8 \mathrm{NPL}$ & $\triangle 4 \mathrm{NPL}$ & $\triangle 8 \mathrm{NPL}$ \\
\hline Credit growth_2y & & $\begin{array}{l}-0.00294 \\
(0.00309)\end{array}$ & & $\begin{array}{l}-0.00246 \\
(0.00448)\end{array}$ & $\begin{array}{c}0.00326 \\
(0.00463)\end{array}$ & $\begin{array}{c}0.00631 \\
(0.00723)\end{array}$ & & \\
\hline GDP growth & & & & & $\begin{array}{l}-0.0171^{* *} \\
(0.00808)\end{array}$ & $\begin{array}{l}-0.0107 \\
(0.0130)\end{array}$ & $\begin{array}{c}-0.0149 * * * \\
(0.00549)\end{array}$ & $\begin{array}{l}-0.00905 \\
(0.00827)\end{array}$ \\
\hline CPI inflation & & & & & $\begin{array}{l}0.00171 \\
(0.0216)\end{array}$ & $\begin{array}{l}-0.0366 \\
(0.0311)\end{array}$ & $\begin{array}{c}-0.000125 \\
(0.0204)\end{array}$ & $\begin{array}{l}-0.0454 \\
(0.0291)\end{array}$ \\
\hline $\mathrm{CA} / \mathrm{GDP}$ & & & & & $\begin{array}{l}0.000472 \\
(0.00361)\end{array}$ & $\begin{array}{c}0.00420 \\
(0.00526)\end{array}$ & $\begin{array}{l}0.000542 \\
(0.00334)\end{array}$ & $\begin{array}{c}0.00366 \\
(0.00474)\end{array}$ \\
\hline Credit gap & $\begin{array}{c}0.0140^{*} \\
(0.00810)\end{array}$ & & $\begin{array}{l}-0.00458 \\
(0.0126)\end{array}$ & & & & $\begin{array}{l}0.0172^{* *} \\
(0.00751)\end{array}$ & $\begin{array}{l}0.0345^{* *} \\
(0.0131)\end{array}$ \\
\hline Constant & $\begin{array}{c}0.00108 \\
(0.000797)\end{array}$ & $\begin{array}{c}0.000578 \\
(0.000825)\end{array}$ & $\begin{array}{l}-0.00123 \\
(0.00131)\end{array}$ & $\begin{array}{l}-0.000264 \\
(0.00121)\end{array}$ & $\begin{array}{l}0.00330 * * \\
(0.00124)\end{array}$ & $\begin{array}{c}0.00178 \\
(0.00202)\end{array}$ & $\begin{array}{c}0.00506 * * * \\
(0.00143)\end{array}$ & $\begin{array}{l}0.00641^{* *} \\
(0.00267)\end{array}$ \\
\hline $\begin{array}{l}\text { Observations } \\
\text { R-squared }\end{array}$ & $\begin{array}{c}53 \\
0.056\end{array}$ & $\begin{array}{c}53 \\
0.017\end{array}$ & $\begin{array}{c}51 \\
0.003\end{array}$ & $\begin{array}{c}51 \\
0.006\end{array}$ & $\begin{array}{c}51 \\
0.161\end{array}$ & $\begin{array}{c}48 \\
0.091\end{array}$ & $\begin{array}{c}51 \\
0.239\end{array}$ & $\begin{array}{c}48 \\
0.203\end{array}$ \\
\hline $\begin{array}{l}\text { Standard errors in } \\
* * * p<0.01, * * p<0\end{array}$ & $\begin{array}{l}\text { parentheses } \\
05, * p<0.1\end{array}$ & & & & & & & \\
\hline
\end{tabular}

\section{Panel estimates confirm that the credit gap is a powerful predictor of systemic} vulnerabilities in the region. In line with the country-specific evidence, panel regression results show that the credit-to-GDP gap is highly significant both at the 1 and 2-year horizons and retains its significance in the augmented model (Table 4). Inflation is also a significant predictor of the change in NPL 1-year ahead with positive sign, while it loses significance 2 -years ahead and so does GDP growth at both horizons. Differently from the countryspecific regressions, however, credit growth is not a significant predictor of future changes in NPLs either alone or in the augmented model. These results hold both when running the analysis with fixed and random effects. 


\begin{tabular}{|c|c|c|c|c|c|c|c|c|}
\hline \multicolumn{9}{|c|}{$\begin{array}{l}\text { Table 4. CAPDR: Early Warning Properties of the Credit Gap } \\
\qquad \text { (Panel Estimates) }\end{array}$} \\
\hline & (1) & (2) & (3) & (4) & (5) & (6) & (7) & (8) \\
\hline VARIABLES & $\triangle 4 \mathrm{NPL}$ & $\triangle 4 \mathrm{NPL}$ & $\triangle 8 \mathrm{NPL}$ & $\triangle 8 \mathrm{NPL}$ & $\triangle 4 \mathrm{NPL}$ & $\triangle 8 \mathrm{NPL}$ & $\triangle 4 \mathrm{NPL}$ & $\triangle 8 \mathrm{NPL}$ \\
\hline Credit growth_2y & & $\begin{array}{c}0.0105 \\
(0.0281)\end{array}$ & & $\begin{array}{c}0.0217 \\
(0.0394)\end{array}$ & $\begin{array}{c}0.000634 \\
(0.0116)\end{array}$ & $\begin{array}{l}0.00233 \\
(0.0179)\end{array}$ & & \\
\hline GDP growth & & & & & $\begin{array}{l}-0.359 \\
(0.577)\end{array}$ & $\begin{array}{c}0.907 \\
(0.916)\end{array}$ & $\begin{array}{l}-0.477 \\
(0.574)\end{array}$ & $\begin{array}{c}0.658 \\
(0.910)\end{array}$ \\
\hline CPI inflation & & & & & $\begin{array}{c}3.210^{* * *} \\
(0.990)\end{array}$ & $\begin{array}{c}2.532 \\
(1.608)\end{array}$ & $\begin{array}{c}2.707^{* * *} \\
(1.005)\end{array}$ & $\begin{array}{c}1.445 \\
(1.649)\end{array}$ \\
\hline $\mathrm{CA} / \mathrm{GDP}$ & & & & & $\begin{array}{l}-5.34 \mathrm{e}-05 \\
(0.000184)\end{array}$ & $\begin{array}{l}-0.000187 \\
(0.000290)\end{array}$ & $\begin{array}{l}-4.74 \mathrm{e}-05 \\
(0.000183)\end{array}$ & $\begin{array}{l}-0.000178 \\
(0.000287)\end{array}$ \\
\hline Credit gap & $\begin{array}{c}1.471^{* * *} \\
(0.466)\end{array}$ & & $\begin{array}{c}3.109 * * * \\
(0.588)\end{array}$ & & & & $\begin{array}{l}0.775^{* *} \\
(0.354)\end{array}$ & $\begin{array}{l}1.383^{* *} \\
(0.570)\end{array}$ \\
\hline Constant & $\begin{array}{c}0.0245 \\
(0.0531)\end{array}$ & $\begin{array}{l}-0.00185 \\
(0.0523)\end{array}$ & $\begin{array}{l}-0.00131 \\
(0.0676)\end{array}$ & $\begin{array}{r}-0.00240 \\
(0.0754)\end{array}$ & $\begin{array}{l}-0.214^{* * *} \\
(0.0643)\end{array}$ & $\begin{array}{c}-0.415^{* * *} \\
(0.106)\end{array}$ & $\begin{array}{l}-0.180^{* * *} \\
(0.0657)\end{array}$ & $\begin{array}{c}-0.331^{* * *} \\
(0.110)\end{array}$ \\
\hline Observations & 425 & 436 & 399 & 410 & 329 & 302 & 330 & 303 \\
\hline R-squared & 0.023 & 0.000 & 0.067 & 0.001 & 0.037 & 0.026 & 0.052 & 0.045 \\
\hline Number of country_code & 7 & 7 & 7 & 7 & 7 & 7 & 7 & 7 \\
\hline $\begin{array}{l}\text { Standard errors in parent } \\
{ }^{* * *} p<0.01, * * p<0.05,{ }^{*} p\end{array}$ & & & & & & & & \\
\hline PANEL ESTIMATES (R & NDOM E & CTS) & & & & & & \\
\hline VARIABLES & $\begin{array}{c}1) \\
\Delta 4 \mathrm{NPL} \\
\end{array}$ & $\begin{array}{c}(2) \\
\Delta 4 \mathrm{NPL} \\
\end{array}$ & $\begin{array}{c}\text { (3) } \\
\Delta 8 \mathrm{NPL} \\
\end{array}$ & $\begin{array}{c}(4) \\
\Delta 8 \mathrm{NPL} \\
\end{array}$ & $\begin{array}{c}(5) \\
\Delta 4 \mathrm{NPL} \\
\end{array}$ & $\begin{array}{c}6) \\
\Delta 8 \mathrm{NPL} \\
\end{array}$ & $\begin{array}{c}7) \\
\Delta 4 \mathrm{NPL} \\
\end{array}$ & $\begin{array}{c}(8) \\
\Delta 8 \mathrm{NPL} \\
\end{array}$ \\
\hline Credit growth_2y & & $\begin{array}{c}0.0101 \\
(0.0279)\end{array}$ & & $\begin{array}{c}0.0207 \\
(0.0392)\end{array}$ & $\begin{array}{c}0.000471 \\
(0.0115)\end{array}$ & $\begin{array}{l}0.00191 \\
(0.0178)\end{array}$ & & \\
\hline GDP growth & & & & & $\begin{array}{c}0.469 \\
(0.368)\end{array}$ & $\begin{array}{c}1.165 \\
(0.768)\end{array}$ & $\begin{array}{l}0.380 \\
(0.372)\end{array}$ & $\begin{array}{l}0.977 \\
(0.768)\end{array}$ \\
\hline CPI inflation & & & & & $\begin{array}{c}2.589 * * * \\
(0.764)\end{array}$ & $\begin{array}{l}2.691^{*} \\
(1.449)\end{array}$ & $\begin{array}{c}2.276^{* * *} \\
(0.779)\end{array}$ & $\begin{array}{l}1.773 \\
(1.494)\end{array}$ \\
\hline $\mathrm{CA} / \mathrm{GDP}$ & & & & & $\begin{array}{c}5.07 \mathrm{e}-05 \\
(0.000171)\end{array}$ & $\begin{array}{l}-0.000132 \\
(0.000283)\end{array}$ & $\begin{array}{c}5.61 \mathrm{e}-05 \\
(0.000171)\end{array}$ & $\begin{array}{l}-0.000121 \\
(0.000280)\end{array}$ \\
\hline Credit gap & $\begin{array}{c}1.372^{* * *} \\
(0.439)\end{array}$ & & $\begin{array}{c}2.860^{* * *} \\
(0.548)\end{array}$ & & & & $\begin{array}{l}0.653^{*} \\
(0.336)\end{array}$ & $\begin{array}{l}1.231^{* *} \\
(0.560)\end{array}$ \\
\hline Constant & $\begin{array}{c}0.0229 \\
(0.0527)\end{array}$ & $\begin{array}{l}-0.00173 \\
(0.0520)\end{array}$ & $\begin{array}{l}-0.00628 \\
(0.0671)\end{array}$ & $\begin{array}{l}-0.00214 \\
(0.0750)\end{array}$ & $\begin{array}{l}-0.272^{* * *} \\
(0.0571)\end{array}$ & $\begin{array}{c}-0.457^{* * *} \\
(0.128)\end{array}$ & $\begin{array}{l}-0.251^{* * *} \\
(0.0582)\end{array}$ & $\begin{array}{c}-0.393 * * * \\
(0.131)\end{array}$ \\
\hline Observations & 425 & 436 & 399 & 410 & 329 & 302 & 330 & 303 \\
\hline Number of country_code & 7 & 7 & 7 & 7 & 7 & 7 & 7 & 7 \\
\hline
\end{tabular}

\section{Activation of the Countercyclical Capital Buffer}

CCyBs based on the estimated credit-to-GDP gap would have been activated during the run-up to the GFC and released during the crisis in most countries. Except for Nicaragua in 2000 and the Dominican Republic in 2003, most countries in the region have not experienced a banking crisis in recent decades, but signs of financial distress were clear around the time of the GFC. Setting CCyB rates according to the BCBS thresholds based on the estimated credit-to-GDP gap would have implied a timely activation of the buffer in the years before the GFC for all countries (Figure 3). In Costa Rica, Guatemala, Honduras, and Nicaragua the buffer would have reached its maximum of 2.5 percent at different stages of the GFC and be released thereafter, although the accumulation phase started as early as 2003 
in Nicaragua ${ }^{7}$. In Panama and El Salvador the CCyB would have also steadily increased and peaked during the crisis but it would have not reached its maximum and would have been released almost immediately suggesting a less steep and protracted credit accumulation. In the Dominican Republic there would have been no activation ahead of the crisis as the system was still recovering from the 2003 banking crisis. The buffers, however, would have built up during the run-up to the 2003 crisis and reached their maximum in 1997, although the suggested pattern is somehow less stable than in other countries. The CCyB would have also been activated during the expansive credit cycles of the late 1990s in Guatemala and Honduras.

Some countries are undergoing an expansionary credit cycle. The Dominican Republic, El Salvador, Nicaragua, and Panama are experiencing an expansion of credit since 2013-2014 as bestowed by the continued accumulation of the putative CCyB in Figure 3 . The CCyB would have already reached its maximum of 2.5 percent in the Dominican Republic and Nicaragua, while El Salvador and Panama have some slack as confirmed also by the decrease in the hypothetical CCyB. However, in the case of Nicaragua the simulated CCyB accumulation is less smooth than during the GFC.

These preliminary results suggest that the $\mathrm{CCyB}$ would have limited the procyclicality of bank lending and further enhance the resilience of the banking systems. However, although the credit gap is a powerful predictor of future financial distress and should be the main indicator to guide policy decisions, the instability of the CCyB accumulation observed in some instances suggests that the information of the credit gap it should be complemented by other macroeconomic and financial variables, and most importantly, by policymakers' judgment to determine the optimal calibration and timing of macroprudential decisions to avoid creating excessive volatility in bank capitalization and uncertainty in agents' behavior (e.g. decision on credit supply).

In general, banks in the region are well capitalized and the $\mathrm{CCyB}$ requirement would have been non-binding in most cases. Based on the simulated CCyB we construct for each country a putative minimum capital requirement including the $\mathrm{CCyB}$. Results show that in most instances over the time horizon for which cross-country comparable aggregate actual capital adequacy ratio (CAR) data series are available, the CCyB would have not been binding for the system as whole. The main exception is Nicaragua, for which the aggregate CAR would have fallen below the minimum requirement plus the $\mathrm{CCyB}$ during the late 1990s. It should be noted that $\mathrm{CCyB}$ policies are not ineffective when they are not binding for the whole banking system. Firstly, because higher regulatory minimum requirements restrict the amount of capital buffer that banks hold voluntary, and this make push banks to further increase their capital to maintain the same level of voluntary buffer. Secondly, even when the system wide CAR does not breach the aggregate capital requirement for the system some individual banks might fail to meet this requirement, and therefore would need to increase their capital levels.

\footnotetext{
${ }^{7}$ In assessing the release phase of the CCyB it needs to be considered that the credit-to-GDP is not necessarily the most appropriate indicator for the release in all circumstances. More timely indicators, such as those based on measures of financial market stress, could prove more effective in some cases.
} 
Figure 4. CAPDR: Activation of the Countercyclical Capital Buffer (Percent of Risk Weighted Assets)
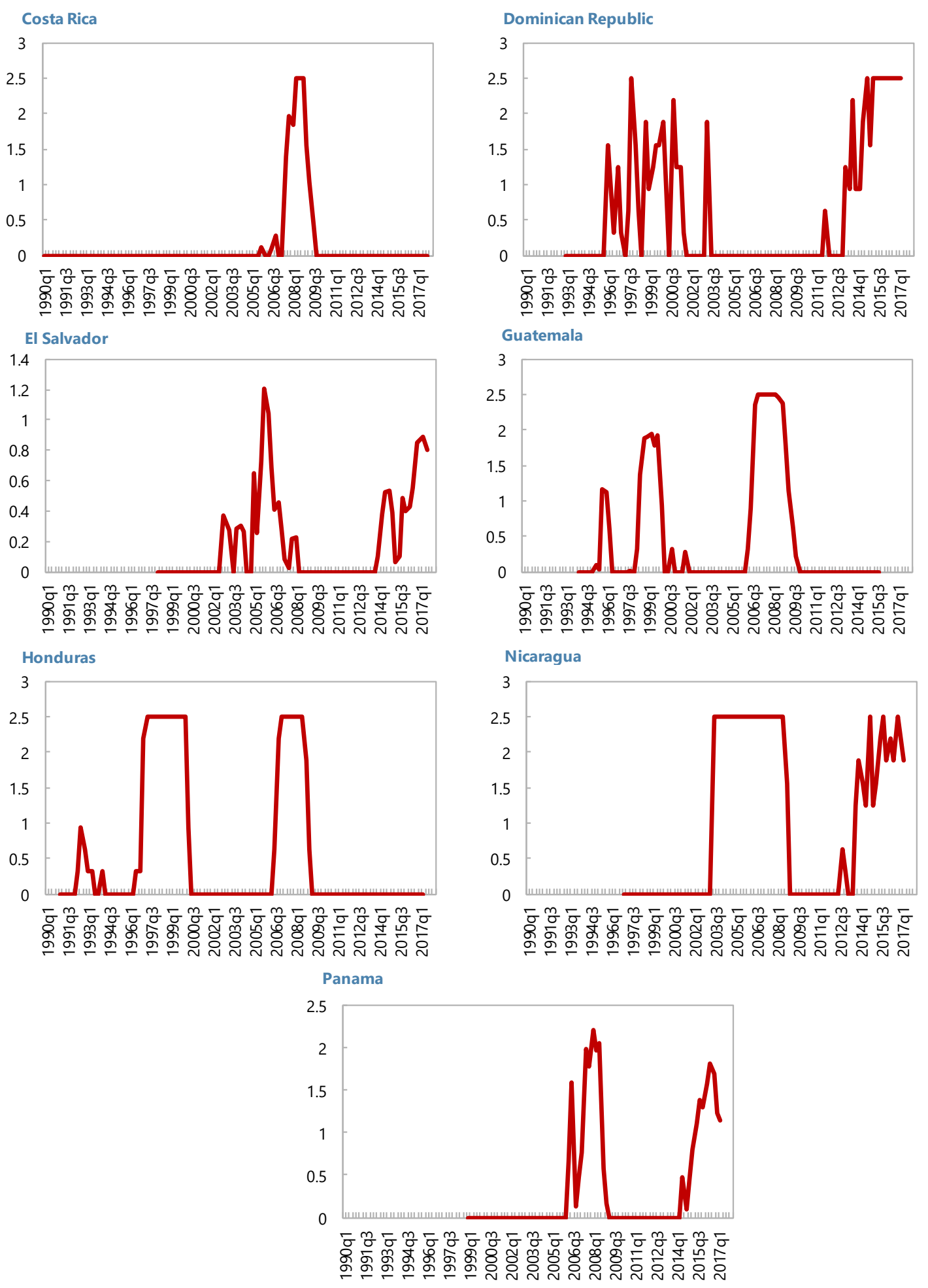

Sources: Authors' estimates. 
Figure 5. CAPDR: System-wide CAR and Simulated Minimum Requirement

(Percent of Risk Weighted Assets)

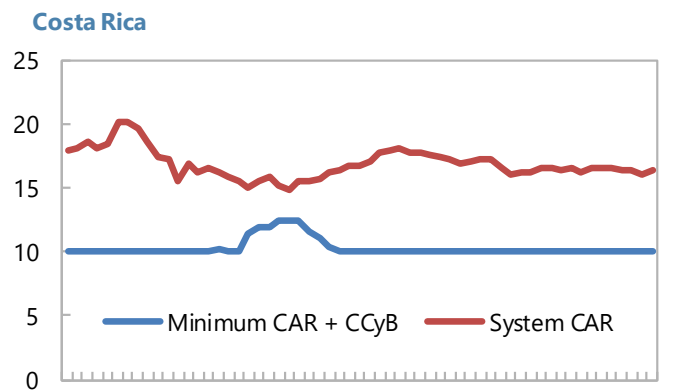

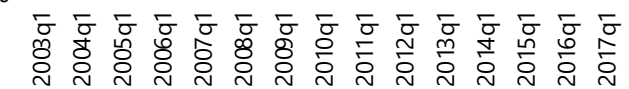
El Salvador

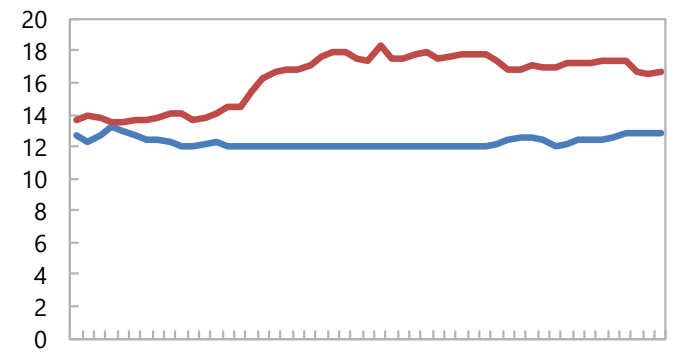

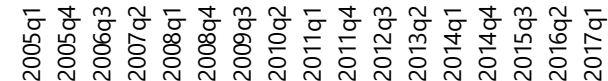
Honduras

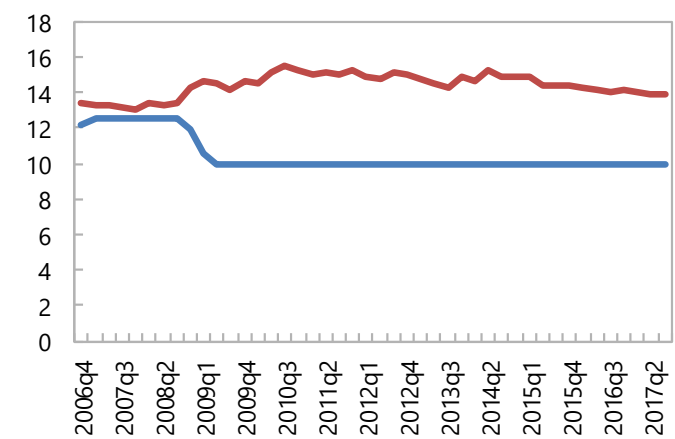

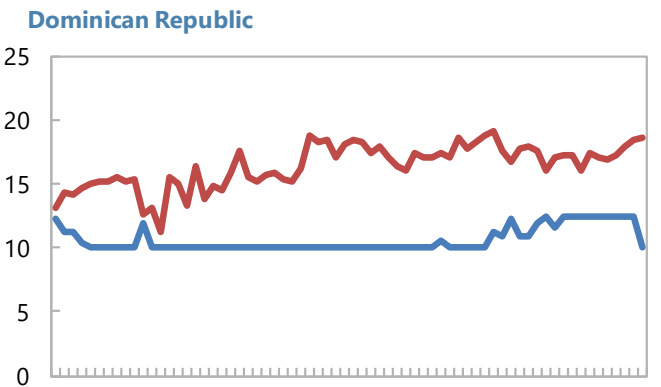

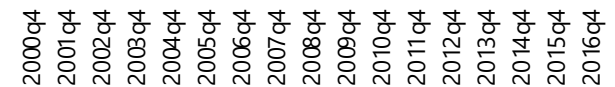
Guatemala

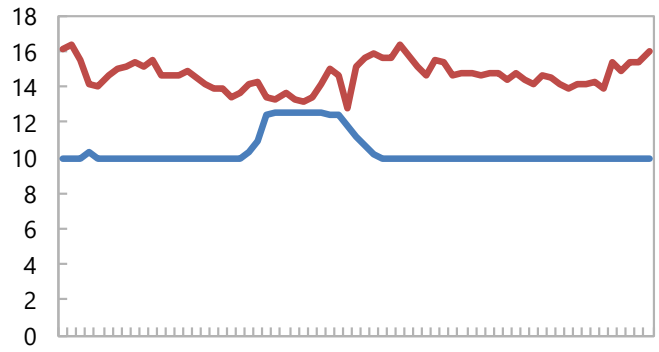

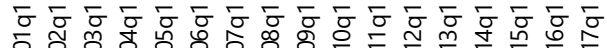

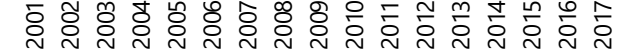
Nicaragua

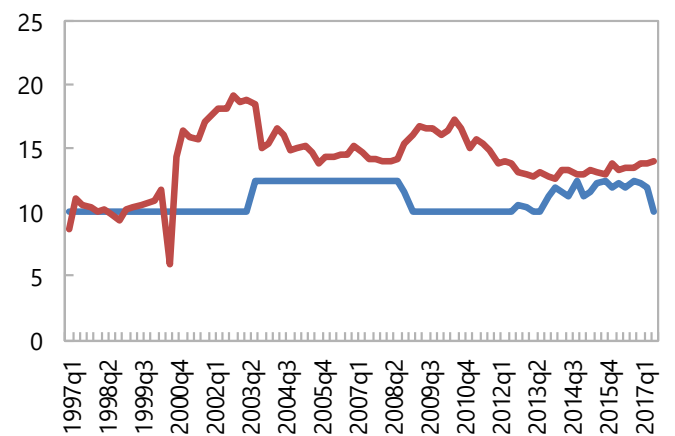

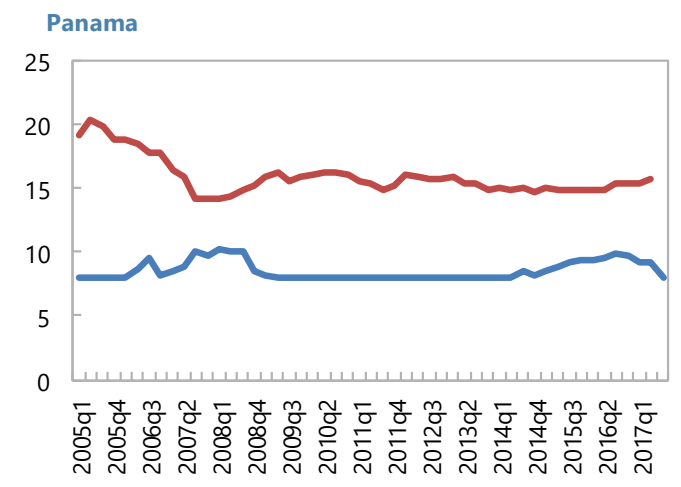

Sources: Authors' estimates. 


\section{Conclusions And Policy Recommendations}

We study the credit cycle in CAPDR using a measure of credit gap that considers the financial deepening ongoing in the region. The analysis shows that since the $1990 \mathrm{~s}$, despite the absence of a significant number of systemic banking crises, most of the countries have experienced at least one credit cycle. The significant synchronicity of the credit cycles confirms the growth of financial linkages within the region.

Credit-to-GDP gap is a powerful early warning predictor of future financial stress in CAPDR. Despite some notable data limitations, the analysis confirms the early warning power of the credit gap in CAPDR countries, in line with the evidence available in the literature for a large number of countries.

Formalizing an analytical framework to assess the applicability of the CCyB in CAPDR should be considered to enhance the stability of the banking system. The signaling power of the credit gap suggests that authorities could consider introducing the CCyB in their policy toolkit. The CCyB would be a useful policy instrument to strengthen the resilience of the banking system through the financial cycle and limit the pro-cyclicality of lending.

\section{Decisions on the CCyB should be based on a deep assessment of the credit}

developments. Although the level of the $\mathrm{CCyB}$ should ideally be anchored mainly to the credit-to-GDP gap, a word of caution is necessary. The performance of the credit-to-GDP for CAPDR, is subject to some caveats, mostly related to existing data limitations. Authorities would need therefore to complement the credit gap with additional analysis. An example would be the use of granular information on credit developments. Micro data can provide important insights into the outlook for financial stability. Whenever credit growth is high, authorities could undertake a forensic analysis of disaggregated loan data to identify which sectors and industries are borrowing - how much, why and at what price.

Qualitative information and judgment should also be used to analyze the changes in lending standards and credit conditions. Regular meetings between the central banks and financial institutions to assess the different views on credit conditions are also helpful. Ultimately, the policy makers need to make sure that any expansion in credit is healthy and understand the reasons behind any credit contraction. Credit deepening must go hand-in-hand with measures that facilitate a healthy credit expansion such as effective legal frameworks for the creation, mobilization and realization of collateral, and effective insolvency proceedings. 


\section{REFERENCES}

Alessandri, P., P. Bologna, R, Fiori, and E. Sette, 2015, A note on the implementation of a Countercyclical Capital Buffer in Italy, Banca d'Italia Questioni di Economia e Finanza (Occcasional Papers), 278.

Allen F. Gale D., 2000, Financial Contagion, Journal of Political Economy, vol.108, N.1.

Basel Committee on Banking Supervision, 2010, Guidance for National Authorities Operating the Countercyclical Capital Buffer (Switzerland: Bank for International Settlements).

Basel Committee on Banking Supervision, 2011, Basel III: A global Regulatory Framework for More Resilient Banks and Banking Systems (Switzerland: Bank for International Settlements).

Borio, C., and P. Lowe, 2002, Assessing the Risk of Banking Crises, Bank for International Settlements Quaterly Review, (December).

Borio, C., and M. Drehmann, 2009, Assessing the risk of banking crises - revisited, BIS Quarterly Review, March, pp. 29- 46.

Claessens, S., M.A. Kose, and M.E. Terrones, 2012, How do business and financial cycles interact?, Journal of International Economics, Elsevier, 87(1), 178-90.

Davis, Scott, 2011, Financial Integration and International Business Cycles Co-movement: Wealth effects vs. Balance sheet effects, Globalization Institute Working Papers 89, Federal Reserve Bank of Dallas.

Drehmann M., C. Borio, and K. Tsatsaronis, 2011, Anchoring countercyclical capital buffers: the role of credit aggregates, International Journal of Central Banking, 7 (4), 189-240.

Drehmann, M., C. Borio, and K. Tsatsaronis, 2012, Characterising the financial cycle: don't lose sight of the medium term!, BIS Working Papers 380, Bank for International Settlements.

Drehmann, M., and M, Juselius, 2014, Evaluating early warning indicators of banking crises: Satisfying policy requirements, International Journal of Forecasting, Elsevier, 30(3), 759-80.

Edge, R.M., and R.R. Meisenzahl, 2011, The Unreliability of Credit-to-GDP Ratio Gaps in Real Time: Implications for Countercyclical Capital Buffers, International Journal of Central Banking, 7(4), 261-98. 
Geršl A., J. Seidler, 2012, Excessive credit growth and countercyclical capital buffers in Basel III: an empirical evidence from central and east European countries, MPRA Paper No. 43689.

Ghosh, A., 2015, Banking-industry specific and regional economic determinants of nonperforming loans: Evidence from US states, Journal of Financial Stability, Vol. 20, issue C, 93-104.

Heng, D., A. Ivanova, R. Mariscal, U. Ramakrishnan, and J. Wong, 2016, Advancing Financial Development in Latin America and the Caribbean, IMF Working Paper WP/16/81: https://www.imf.org/external/pubs/ft/wp/2016/wp1681.pdf

International Monetary Fund, 2016, Financial Integration in Latin America, IMF Policy Paper: https://www.imf.org/external/np/pp/eng/2016/030416.pdf

Kaminsky, G., and C. Reinhart, 1999, The Twin Crises: The Causes of Banking and Balanceof-Payments Problems, American Economic Review, 89 (3), 473-500.

Laeven, L., and F. Valencia, 2008, Systemic Banking Crises: A New Database," IMF Working Paper 08/224, (Washington: International Monetary Fund).

Lund-Jensen, K., Monitoring Systemic Risk Based on Dynamic Thresholds, 2012, IMF Working Paper 12/159.

Mink, M., J. Jacobs, and J. De Haan (2012). Measuring coherence of output gaps with an application to the euro area. Oxford Economic Papers, 64 (2), 1-20.

Orphanides A., and S. van Norden, 2002, The unreliability of output gap estimates in real time, The Review of Economics and Statistics, 84(4), 569-83.

Ramírez de León, F. A., 2012, Crédito al Sector Privado en Republica Dominicana (19972011): ¿Existe Evidencia de Racionamiento del Crédito? Serie de Estudios Economicos No. 7, Banco Central de la República Dominicana, Santo Domingo.

Reserve Bank of India, 2013, Implementation of Counter-cyclical Capital Buffer, (December).

Samarina, A., L. Zhang, and D. Bezemer,2017, Credit Cycle Coherence in the Eurozone: Was There a Euro Effect?, Journal of International Money and Finance, 77, 77-98.

Schularick, M., and A. M. Taylor, 2012, Credit Booms Gone Bust: Monetary Policy, Leverage Cycles, and Financial Crises, 1870-2008, American Economic Review, 102(2), 1029-61. 


\section{APPENDiX: DATA DESCRIPTION}

Total credit is computed separately for each country, however, in each case we have tried to cover the universe of all possible debt and debt like instruments extended to the nonfinancial private sector. Created in this way, total credit is the total amount of outstanding bank loans and other credit from finance companies and cooperatives and bonds, if applicable. The data for each country was requested separately from the relevant authorities. Credit growth rate is the year over year growth rate in the total credit.

GDP is quarterly nominal gross domestic product from Haver analytics. The seasonally adjusted series is used for the calculation of the HP filtered GDP series, while the nonseasonally adjusted series is used for the calculation of the credit to GDP ratio.

Credit to GDP ratio is the total amount of outstanding credit in a specific quarter divided by the cumulative GDP, not seasonally adjusted, in the previous four quarters.

Inflation is the year on year growth rate of the consumer price index from Haver Analytics.

Output gap is measured by applying a one-sided HP filter with a parameter 1600 to the $\log$ of seasonally adjusted GDP series.

Credit gap is measured by applying the one-sided HP filter with a parameter of 400000 to the log of credit to GDP ratio.

NPL ratio is defined as the total amount of outstanding bank loans that is delinquent for more than "90" days to total amount of bank loans. The data are submitted by the relevant authorities of each of the countries in the sample. The change in NPL ratio is simply the forward-looking change in this ratio at different horizons.

Current Account is downloaded from Haver Analytics. Current account to GDP ratio is the quarterly value of current account divided by the annual GDP of the previous year. 


\begin{tabular}{|c|c|c|c|c|c|c|c|}
\hline \multicolumn{8}{|c|}{ Table A1: Data Time Period by Country } \\
\hline & Costa Rica & Honduras & Guatemala & EI Salvador & Nicaragua & Panama & $\begin{array}{c}\text { Dominican } \\
\text { Republic }\end{array}$ \\
\hline \multicolumn{8}{|l|}{ Variable } \\
\hline NPL & $2000 q 1-2015 q 4$ & $2006 q 4-2017 q 2$ & $2000 q 1-2015 q 4$ & $1993 q 1-2017 q 3$ & $1995 \mathrm{q} 1-2017 \mathrm{q} 2$ & $2003 q 2-2017 q 2$ & $2000 q 4-2017 q 3$ \\
\hline Total Credit & $1997 q 4-2015 q 4$ & $1990 \mathrm{q} 1-2017 \mathrm{q} 2$ & $1994 q 4-2015 q 4$ & $1998 \mathrm{q} 1-2017 \mathrm{q} 3$ & 1996q1-2017q2 & $1999 q 1-2017 q 2$ & $1993 q 1-2017 q 2$ \\
\hline GDP & $1996 q 4-2015 q 4$ & $1990 \mathrm{q} 1-2017 \mathrm{q} 2$ & $1993 q 4-2015 q 4$ & $1990 \mathrm{q} 1-2017 \mathrm{q} 2$ & 1996q1-2017q2 & $1994 q 1-2017 q 2$ & $1993 q 1-2017 q 2$ \\
\hline Inflation & $1997 q 4-2015 q 4$ & $1990 \mathrm{q} 1-2017 \mathrm{q} 2$ & $2001 q 1-2015 q 4$ & $1991 \mathrm{q} 1-2017 \mathrm{q} 3$ & 2006q1-2016q2 & $2003 q 2-2016 q 3$ & $1993 q 1-2017 q 2$ \\
\hline Current Account & $1999 q 1-2015 q 4$ & $2004 q 1-2016 q 4$ & $2004 q 1-2015 q 4$ & 1999q1-2017q2 & $2005 q 1-2016 q 2$ & $2000 q 1-2017 q 2$ & $1993 q 1-2017 q 2$ \\
\hline \multicolumn{8}{|c|}{$\begin{array}{l}\text { Table A1. This table presents the data availability for each country and each time period. Note that the startng point for the total credit variable indicates the point at which the } \\
\text { data is used to create the credit gap measure. As discussed in the paper, this point is chosen such that no structural breaks exists in the sample. } \\
\text { Note: The starting point for the total credit variable indicates the point at which the data is used to create the credit gap measure. As discussed in the paper, this point is chosen } \\
\text { such than no structural breaks exist in the sample. }\end{array}$} \\
\hline
\end{tabular}

\section{CInternational Monetary Fund. Not for Redistribution}

